\title{
Female CEOs and Core Earnings Quality: New Evidence on the Ethics Versus Risk-Aversion Puzzle
}

\author{
Alaa Mansour Zalata ${ }^{1,2} \cdot$ Collins Ntim $^{1} \cdot$ Ahmed Aboud $^{3,4} \cdot$ Ernest Gyapong $^{5}$
}

Received: 25 July 2017 / Accepted: 3 May 2018 / Published online: 24 May 2018

(c) The Author(s) 2018

\begin{abstract}
The question of whether females tend to act more ethically or risk-averse compared to males is an interesting ethical puzzle. Using a large sample of US firms over the 1992-2014 period, we investigate the effect that the gender of a chief executive officer (CEO) has on earnings management using classification shifting. We find that the pre-Sarbanes-Oxley (SOX) Act period was characterized by high levels of classification shifting by both female and male CEOs, but the magnitude of such practices is, surprisingly, significantly higher in firms with female CEOs than in those with male CEOs. By contrast, our results suggest that following the passage of the punitive SOX Act, classification shifting by female CEOs declined significantly, whilst it remained pervasive in firms with male CEOs. This suggests that the observable differences in financial reporting behavior between male and female CEOs seem to be because female CEOs are more risk-averse, but not necessarily more ethically sensitive than their male counterparts are. The central tenets of our findings remain unchanged after several additional checks, including controlling for alternative earnings management techniques, corporate governance mechanisms, CEO and chief financial officer characteristics and propensity score-matching.
\end{abstract}

Keywords Female CEOs $\cdot$ Earnings quality $\cdot$ Classification shifting

\section{Introduction}

The introduction in the 1960s of a number of gender-focused equal opportunities laws, especially in developed countries, such as the 1963 Equal Pay Act of the US, helped in increasing women's participation in the workforce (Khlif and Achek 2017). However, this did not necessarily lead to increased participation of women in senior management roles [e.g., board member or chief executive officer (CEO)] in companies, with 'old-boys networks' often cited as one

Alaa Mansour Zalata

a.zalata@soton.ac.uk

1 Southampton Business School, University of Southampton, Southampton SO17 1BJ, UK

2 Faculty of Commerce, Mansoura University, El Mansura, Egypt

3 Portsmouth Business School, University of Portsmouth, Portland Street, Portsmouth PO1 3AH, UK

4 Faculty of Commerce, Beni-Suef University, Beni Suef, Egypt

5 School of Accounting, Massey Business School, Massey University, Palmerston North, New Zealand of the major barriers to women's executive career progression (Adams 2016). The past three decades have, however, witnessed significant increases in corporate, national and supra-national governance reforms, laws and affirmative initiatives explicitly aimed at increasing women's participation in senior corporate executive roles (Adams 2016; Srinidhi et al. 2011). For instance, Canada, the EU, France, Norway, Italy and the UK have implemented either 'hard' or 'soft' gender-based quotas for large corporate board memberships, which have led to observable increases in women's presence on corporate boards in these countries (Adams 2016; Adams and Ferreira 2009; Srinidhi et al. 2011).

Discernibly, the strong push for gender-diverse corporate boards and executives is not only driven by ethical, moral and social fairness theories (Sun et al. 2017), but also economic benefits of the unique skills, experiences and talents that women bring to such roles (Carter et al. 2003, 2010). Unsurprisingly, a number of distinct empirical strands of research have emerged. An earlier relevant strand has examined the effect that gender-diverse corporate boards and women CEOs have on firm performance/value (Carter et al. 2003, 2010). With some exceptions (see Adams and Ferreira 2009; Kirsch 2017; Terjesen et al. 2009), the findings 
suggest that gender has a positive effect on firm performance/value (Carter et al. 2003; Gul et al. 2011; Liu et al. 2014; Ntim 2015; Shrader et al. 1997). ${ }^{1}$ Such positive gender effects have been attributed to rational-economic inspiredtheories, such as agency, resource dependence, stakeholder and stewardship theories, which indicate that the presence of women in boardrooms enhances board independence, monitoring, advisory capacity and resources through greater connection of the firm to the external environment (Adams 2016; Kirsch 2017; Terjesen et al. 2009).

A more recent strand of the literature has focused on the effect that gender-diverse corporate boards and women CEOs have on corporate fraud and wrong-doing (Ho et al. 2015; Palvia et al. 2015; Peni and Vahamaa 2010; Sun et al. 2017). For example, existing evidence indicates that the presence of women on corporate boards: (i) reduces the probability of corporate fraud (Capezio and Mavisakalyan 2016; Cumming et al. 2015), (ii) enhances earnings quality (Peni and Vahamaa 2010; Srinidhi et al. 2011; Zalata et al. 2018); and reduces the likelihood of financial statement re-statements (Abbott et al. 2012). Similarly, several findings suggest that executive female directors are associated with: (i) more conservative financial reporting (Ho et al. 2015; Palvia et al. 2015), (ii) higher accounting quality (Barua et al. 2010b), and (iii) lower fraudulent financial reporting (Sun et al. 2017). However, others have indicated that female auditors are less likely to issue a going-concern decision for financially distressed clients (Hossain et al. 2016). Unlike the performance-enhancing motives for appointing women, the preventive benefits of gender-diverse boards have been explained mainly by behavioral, psychological and social theories (Bernardi and Arnold 1997; Croson and Gneezy 2009). For instance, women are perceived to be more ethical and risk-averse, and are generally more responsive to moral development (Bernardi and Arnold 1997; Croson and Gneezy 2009).

One problem with the existing accounting studies is that they often concurrently use these two theories to underpin these gender differences (i.e., Cumming et al. 2015; Ho et al. 2015; Palvia et al. 2015; Peni and Vahamaa 2010; Sun et al. 2017). First, gender might affect earnings management level because women seem to be more concerned with ethical issues and tend to act more ethically when facing a dilemma (Bernardi and Arnold 1997; Croson and Gneezy 2009). This can foster more honesty in financial reporting and potentially discourage earnings management (Ho et al. 2015; Peni and Vahamaa 2010).

\footnotetext{
${ }^{1}$ Gender has also been demonstrated to have a positive effect on other corporate outcomes, such as CSR (Mcguinness et al. 2017), compensation (Baixauli-Soler et al. 2016) and disclosure (Hughey and Sulkowski 2012).
}

Second, female directors tend to be more risk-averse (Croson and Gneezy 2009) and, therefore, are less likely to engage in aggressive earnings management (Peni and Vahamaa 2010; Srinidhi et al. 2011). Noticeably, the evidence of women being more ethical and/or risk-averse leads to the same conclusion-that women are, on average, less likely to engage in earnings management than their male counterparts are (Palvia et al. 2015; Peni and Vahamaa 2010).

We contend that one reason for previous studies' inability to provide direct reasons for the differences between female and male directors' opportunistic decisions might be their research design. In particular, past studies (Cumming et al. 2015; Peni and Vahamaa 2010; Sun et al. 2017) have focussed on accruals-based earnings management (AEM) that became a costly method rather than other, arguably less costly, methods, particularly after financial scandals in the early 2000s, such as Enron and WorldCom, which were followed by the issuance of some restrictive regulations, such as the 2002 Sarbanes-Oxley (SOX) (Chen et al. 2012; McNichols 2000; Stubben 2010). Accordingly, AEM has, arguably, become costly due to its detection cost (Abernathy et al. 2014; Alfonso et al. 2015), which in turn might lead managers to seek other earnings management methods that are relatively more difficult to detect if they hope to garner the benefit of earnings management (Abernathy et al. 2014; Lo 2008; Zalata and Roberts 2016, 2017).

A major question that has been investigated less often, however, is whether women executives are more ethical or risk-averse. A priori, if women are more risk-averse than ethical, then we conjecture that, when facing the possibility of costly legal action, they are more likely to shift to a more subtle, less risky and difficult-to-detect corporate activity (Abernathy et al. 2014; Alfonso et al. 2015), albeit equally un-ethical (Zalata and Roberts 2016, 2017). The opposite may hold if women are more ethical than men are. The 2002 SOX Act and its associated regulations, such as 'Regulation G' offer a unique empirical setting to test these propositions. Following the introduction of SOX, AEM became extremely costly and risky for directors, with potentially lengthy prison terms and large personal financial penalties (Cohen et al. 2008; McNichols 2000; Stubben 2010; Zang 2012). In this case, we argue that if female CEOs are more risk-averse, but not necessarily more ethical than men, then, they might change to less costly forms of earnings management, in this case, "classification shifting, ${ }^{2}$ which is

\footnotetext{
${ }^{2}$ We note, however, that the increased regulatory framework, such as SOX and 'Regulation G' along with greater focus by the US government, SEC, financial accounting standards board, analysts, auditors, accounting bodies, investors, owners and directors on financial reporting during this period meant that the use of all forms of financial accounting manipulations (e.g., fraud, accruals-based earnings management, real earnings management and classification shifting) became costly and risky, and therefore it is likely that female CEOs'
} 
equally un-ethical, ${ }^{3}$ but difficult for enforcement authorities to detect (Abernathy et al. 2014; Chen et al. 2012; McNichols 2000).

Unlike traditional fraudulent, accruals-based and real earnings management (REM), 'classification shifting' is a subtle form of earnings management that involves a deliberate attempt at misclassifying the presentation of some core expenses as special expenses within the income statement (McVay 2006; Zalata and Roberts 2016, 2017). As classification shifting ${ }^{4}$ is both less risky and un-ethical, but rarely studied (Abernathy et al. 2014; Alfonso et al. 2015), it allows us to make unique contributions to the existing literature by testing our propositions. Consequently, the main objective of this study is to investigate the effect that the gender of the $\mathrm{CEO}^{5}$ has on earnings management, using classification shifting. We focus on classification shifting since the extant literature (e.g., Fan et al. 2010; McVay 2006) has already documented that some firms use classification shifting to deceive investors, particularly when they are constrained from using accruals. In addition, Alfonso et al. (2015) show that investors tend to misprice underlying earnings that have been deliberately overstated by classification shifting, and thereby suggesting that investors, particularly small investors (Allee et al. 2007), can be at risk of being misled by classification shifters' opportunistic practices.

Arguably, since classification shifting does not change the bottom-line net income, it is less likely to undergo scrutiny by regulators or external auditors than AEM might be (Abernathy et al. 2014; McVay 2006). Furthermore, classification

\footnotetext{
Footnote 2 (continued)

ability to shift to or use classification shifting post-SOX became equally constrained (Abernathy et al. 2014; Chen et al. 2012).

${ }^{3}$ Further, we note that during the spectacular corporate collapses of Enron, WorldCom and others in the early 2000s along with their major negative social and economic consequences, the un-ethical and immoral nature of all types of earnings management became easily self-evident among corporate executives, the media and the general public (Barua et al. 2010a; Bruns and Merchant 1990; Merchant and Rockness 1994)

${ }^{4}$ Classification shifting is used to inflate core earnings or earnings before special items (Alfonso et al. 2015; Haw et al. 2011; McVay 2006). Arguably, managers are motivated to inflate their core earnings rather than the bottom-line net income because most investors currently base their investment decisions on this number (Bhattacharya et al. 2007; Bradshaw and Sloan 2002; Elliott 2006). In addition, the extant research suggests that debt markets also pay more attention to this number (Dyreng et al. 2016; Li 2010). This might motivate companies to engage in classification shifting.

${ }^{5}$ In robustness checks, and following past evidence (Jiang et al. 2010), we control for the CFO's gender and other gender-relevant characteristics of the CEO, as well as alternative earnings management techniques, such as real earnings management.
}

shifting involves neither accruals reversal in succeeding periods, nor the foregoing of returns or increased costs of real business management (Athanasakou et al. 2009; McVay 2006). All these factors might suggest that earnings management through classification shifting will incur lower costs than AEM or REM would (Zalata and Roberts 2016, 2017). Nevertheless, only few studies have investigated classification shifting, and those that have done so, have suggested that firms employ it as a tool to meet their earnings' targets, particularly in firms constrained from using accruals to inflate their earnings (e.g., Barua et al. 2010a; Fan et al. 2010; Haw et al. 2011; McVay 2006). A major limitation of the few existing studies (Abernathy et al. 2014; Alfonso et al. 2015; Fan et al. 2010; Haw et al. 2011; Zalata and Roberts 2016, 2017) is that they have often treated all CEOs engaged in classification shifting as the same, irrespective of their background, specifically their gender origins. Extant research has shown that CEOs' reputation, financial expertise, tenure, and age have an impact on their motivation and ability to engage in earnings management (i.e., Ali and Zhang 2015; Francis et al. 2008; Huang et al. 2012; Jiang et al. 2013). However, since the appointment of women in top executive positions is relatively low, we focus on CEOs gender. Whilst past studies (Arun et al. 2015; Barua et al. 2010b; Cumming et al. 2015; Francis et al. 2015; Owhoso 2002; Peni and Vahamaa 2010; Sun et al. 2011) have examined the effect that gender has on less sophisticated forms of earnings management, such as fraud and AEM, little, however, is known about whether there are gender differences in the use of such sophisticated and subtle earnings management techniques, such as classification shifting. The current study, therefore, seeks to extend prior studies by focussing on classification shifting. By so doing, we not only extend gender studies to a new territory, but also provide new insights with respect to the debate on whether female CEOs are really more ethical and/or risk-averse than their male counterparts are. In particular, we argue that if women are more risk-averse than ethical, then, they will readily shift to less risky and more sophisticated forms of earnings management methods - and in this case, 'classification shifting' - instead of the now highly risky, AEM, but which is nonetheless equally un-ethical. The opposite will be the case if women are more ethical than men are.

Using a sample of US firms from 1992 to 2014, we find that there are no significant differences between female and male CEOs in terms of classification shifting for the whole sample period. Interestingly, we find that the passage of SOX has an impact upon female CEOs' preference towards classification shifting. In particular, we document that the pre-SOX period was characterized by increasing classification shifting by both female and male CEOs, although this was more prominent in firms with female CEOs than in firms with male CEOs. Following the passage of SOX, 
classification shifting by female CEOs (as risk-averse) declined significantly, whilst it became more pervasive in firms with male CEOs. This suggests that female CEOs do not consider classification shifting as a viable earnings management method after the passage of SOX, and therefore demonstrating that the strong legal environment appears to have affected their preference towards classification shifting. Given this, our findings suggest that female CEOs are more risk-averse, but they are not necessarily more ethical than their male counterparts are. ${ }^{6}$ In addition, this study examined the impact of female CEOs upon classification shifting activities for a subset of firms that are more likely to have managed their earnings. Specifically, we undertook the analysis for two subsamples, namely, firms with CEOs holding high stock ownership and low-debt firms. The results of this analysis suggest that female CEOs had significantly higher classification shifting before the passage of SOX, whilst they used significantly less classification shifting in post-SOX. Together, our evidence demonstrates that differences between female and male CEOs in financial reporting decisions appear to be explained more by the fact that female CEOs are more risk-averse compared with their male counterparts, and less by the existing evidence that they are more ethical than men are. Thus, although women appear to be generally both more risk-averse and ethical than men, our evidence shows further that in a situation of extreme dilemma, their risk-aversion instinct is highly likely to take precedence over their ethical orientation.

This study contributes to the accounting literature in many ways. First, while the extant classification-shifting research focusses on neoclassical determinants of classification shifting either at the firm (i.e., Zalata and Roberts 2016) or country (i.e., Haw et al. 2011) level, our paper seeks to relate CEOs' gender to classification shifting. That is, our paper contributes to the earnings management literature

\footnotetext{
${ }^{6}$ As a mark of caution, our findings can also be interpreted to mean that the un-ethical nature of all forms of earnings management became more evident to corporate executives, including women executives during the major corporate collapses of the 2000s, such as Enron, that preceded the introduction of SOX (Abernathy et al. 2014; Chen et al. 2012). It is, therefore, possible that women did not view earnings management through the lens of ethical behavior until after these frauds that led to the passing of the SOX legislation occurred. Consequently, if women were to subsequently change their reporting behavior once they began to see earnings management as an ethical act following its publicity, then, it can be argued that differences in ethics between men and women could equally explain our current findings. Therefore, the reduction (increase) in the use of classification shifting in firms with female (male) CEOs can also be ascribed to women being more ethically sensitive than men are. Our findings can, therefore, be attributed to or explained by the ethical theory as well. We thank an anonymous referee for pointing out this possible alternative explanation of our findings to us. We have also discussed this possible alternative explanation of our findings, as part of the limitations in our concluding remarks.
}

by offering evidence for the first time that shows that the level of classification shifting is a function of CEOs' gender, particularly after considering the impact of the legal environment (i.e., the passage of SOX). Second, while most prior gender and ethics studies (Ibrahim and Angelidis 2009; Lund 2008; Owhoso 2002; Simga-Mugan et al. 2005) have used surveys to investigate whether females are more ethical than their male counterparts are, we extend them by using actual data relating to financial reporting. In contrast to these studies, our findings suggest that female CEOs are more risk-averse, but not necessarily more ethical than their male counterparts are. In this case, our paper provides new insights on the theoretical explanation underpinning the observable differences between female and male CEOs. In particular, it shows that while male CEOs see classification shifting as a viable earnings management method in pre- and post-SOX periods, female CEOs have reduced their use of this method after the passage of SOX. This result suggests that the differences in financial reporting behavior between male and female CEOs seem to be because female CEOs are more risk-averse, but not necessarily more ethical than their male counterparts are. Finally, the results of this study have implications for boards of directors in terms of informing their decisions regarding CEOs appointments; and for users of financial statements. Our findings suggest that they should consider not only the gender of CEOs, but also the legal environment as factors that can potentially influence the propensity for CEOs to manage earnings.

The rest of the paper is structured as follows. "Literature Review and Hypotheses Development" section reviews the related literature and develops the main hypotheses. "Research Method" section describes the research design, and discusses the sample and data sources. "Results" section discusses the results, while "Conclusion" section concludes the study and discusses our study limitations.

\section{Literature Review and Hypotheses Development}

The number of female CEOs in top US firms is growing, although it is still far from reflective of the percentage of women in the workforce in general (Ho et al. 2015). For example, women currently hold about $4 \%$ of CEOs positions at S\&P 500 companies compared with 2\% in 2006 (Creswell 2006). This increasing representation of women within the CEO ranks has motivated researchers to investigate whether female leaders have changed corporate behavior and attributes. Huang and Kisgen (2013) noted that it is important to investigate this research question, not only because it provides more insights into corporate behavior, but also because the representation of women in top executive positions continues to be relatively low. 
Extant research provides different theoretical explanations as to why women and men exhibit distinct business behaviors (Abbott et al. 2012; Peni and Vahamaa 2010; Srinidhi et al. 2011). In particular, researchers have identified two main factors that might drive the different business behavior among women and men, namely attributes relating to their (i) ethical stands and (ii) risk preferences (Croson and Gneezy 2009; Palvia et al. 2015). This is important because these ethical attributes are central to the conceptualization of female leadership (Fine 2009; Ho et al. 2015). Despite the lack of a theoretical framework ${ }^{7}$ that can explain why women are more ethically sensitive than men (Collins 2000), the findings of a number of prior studies have suggested that women are more ethically sensitive than their male rivals are (i.e., Ibrahim and Angelidis 2009; Lund 2008; Owhoso 2002; Simga-Mugan et al. 2005). In his review article, Collins (2000) found that 32 studies out of 47 revealed that women are more ethically sensitive than men are. Ho et al. (2015) postulated that the stronger ethical nature of female leaders translates into stronger ethical leadership, and hence a more ethical work climate, which can foster greater levels of honesty in financial reporting, and thereby potentially discouraging earnings management. However, most ethics studies (Ibrahim and Angelidis 2009; Lund 2008) base their analysis on data collected from surveys often with low response rates, which thus might cast doubt on the validity of their inferences. Apart from the low response rates (Owhoso 2002), respondents may not accurately report their ethical actions (Simga-Mugan et al. 2005), and therefore these studies arguably need to be backed by evidence from actual archival data (Ho et al. 2015; Palvia et al. 2015).

Another strand of studies (Croson and Gneezy 2009; Faccio et al. 2016; Martin et al. 2009) has investigated gender impact on risk aversion and indicates that female executives are more risk-averse than male executives are. Byrnes et al. (1999), for example, reviewed 150 psychology studies and found that female participants are less likely than male participants to take risk. Prior studies have also shown that this risk attitude is prevalent in accounting, economics, finance and management decisions (Barua et al. 2010b; Croson and Gneezy 2009). For example, in their experimental study, Powell and Ansic (1997) found that females tend to avoid making risky financial decisions compared to their male counterparts. Martin et al. (2009) observed significant reductions in risk levels following female CEO appointments compared with male CEO appointments. Faccio et al. (2016)

\footnotetext{
${ }^{7}$ Note though that females often depict certain characteristics, such as being less aggressive, assertive, competitive and overconfident, but more anxious, cautious, collaborative, risk-averse, emotional and socially responsive than males; all qualities that, in theory, are likely to arguably compel women to act more ethically in a given ethical dilemma than men would (Croson and Gneezy 2009; Ho et al. 2015).
}

showed that firms with female CEOs have lower leverage, less volatile earnings and a higher chance of survival than do firms with male CEOs. Furthermore, Huang and Kisgen (2013) found that female CEOs are more cautious when making financial decisions; in particular, they found that firms with female CEOs grow more slowly, are less likely to make acquisitions, and are less likely to issue debt. All these appear to suggest that female CEOs tend to avoid taking risky decisions. However, Atkinson et al. (2003) found no significant differences between male and female CEOs in terms of risk-taking.

Based on these different attributes between women and men, the extant research has investigated whether female CEOs bring different values to their firms compared with their male counterparts; for example, Carter et al. (2003, 2010), Francoeur et al. (2008) and Welbourne et al. (2007) found that the presence of female executives in top management has a positive association with their firms' performance. However, this improved performance can be achieved through better operating decisions and work environment or through opportunistic financial reporting decisions or earnings management. Earnings management is one of the key ethical issues and raises the most important ethical dilemmas facing corporate executives (Bruns and Merchant 1990; Merchant and Rockness 1994; Sun et al. 2011). However, while there has been a dearth of studies investigating whether executive directors' gender affects their willingness to engage in earnings management, the extant literature, discussed in detail below, shows, to some extent, a low propensity of female directors to engage in earnings management (Ho et al. 2015; Palvia et al. 2015).

Whilst Ge et al. (2011) and Ye et al. (2010) failed to support this proposition, some other studies document significant differences between male and female executives on financial reporting quality (Capezio and Mavisakalyan 2016; Peni and Vahamaa 2010; Srinidhi et al. 2011). For example, Francis et al. (2014) showed that female executives are associated with less tax aggressiveness. Similarly, Francis et al. (2015) and Ho et al. (2015) showed that female executives are more conservative in their financial reporting than their male counterparts are. In terms of earnings management, Krishnan and Parsons (2008) found that the presence of female executives within the top management level is positively related to earnings quality or low earnings management. In supporting this, Barua et al. (2010b) found that firms with female chief financial officers (CFOs) have lower AEM. Focussing on blatant cases of manipulation, Cumming et al. (2015) showed that the probability of fraud is lower in firms with more female representatives. However, Arun et al. (2015) reported that female directors constrain upward AEM and encourage downward earnings management. Nonetheless, the role of gender differences in securing the integrity of financial reports is not fully understood 
(Barua et al. 2010b; Ho et al. 2015), and the extant research is yet to provide a direct explanation for why female CEOs are less likely to engage in earnings management than their male counterparts are. ${ }^{8}$

Furthermore, prior studies (Cumming et al. 2015; Peni and Vahamaa 2010; Sun et al. 2017) have investigated the relationship between female CEOs and AEM that, arguably, has higher potential litigation and reputation costs because of the intense public and regulatory scrutiny (Abbott et al. 2012), particularly after the financial scandals in 2000 (Barua et al. 2010b; Bruns and Merchant 1990; Merchant and Rockness 1994). Consequently, we argue that if female CEOs are more risk-averse than ethical, then they may be less inclined to engage in AEM largely because of the significant associated risk. By contrast, when they are not affected by either regulation or litigation risk, they perhaps might equally use earnings management, but a more subtle/ sophisticated one to outperform the market if female CEOs are equally un-ethically oriented, as their male counterparts are. $^{9}$ As such, classification shifting arguably provides a powerful setting to investigate this proposition. Unlike AEM, classification shifting is not related to the measurement or recognition of items (Fan et al. 2010; Haw et al. 2011); rather it is related to the appropriate categorization of expenses within the income statement (McVay 2006; Zalata and Roberts 2016). The appropriate categorization is subject to high managerial discretion, and therefore regulators and external monitors might have limited ability to verify it (Zalata and Roberts 2017), leading to lower litigation and reputation concerns (or low risk) than concerns about AEM (Alfonso et al. 2015; McVay 2006).

To the best of our knowledge, there are no cases, where CEOs have been sued for engaging in classification shifting to-date (Zalata and Roberts 2016, 2017). Consequently, in such a relatively low-risk setting (Abernathy et al. 2014; Alfonso et al. 2015), it is reasonable to expect a different behavior of female CEOs (they might manage their earnings using classification shifting to a higher extent than male CEOs would; or at least at the same level), if they do have the willingness to manage earnings in order to influence financial performance, as male CEOs tend to do (Barua et al. 2010b; Croson and Gneezy 2009). In addition,

\footnotetext{
${ }^{8}$ We note, however, that our goal is not to provide an explanation as to why female CEOs are less likely to engage in earnings management than their male counterparts are. Instead, our goal is to simply show that women behave differently in the post-SOX period with one method for earnings management (i.e., classification shifting). More conclusive evidence can be offered by future researchers by using different earnings management techniques, such as accruals, classification shifting and real earnings management methods, and ideally set up within both risk and ethical settings.

${ }^{9}$ It should, however, be noted the opposite case will equally be expected to hold if female CEOs are more ethical than male CEOs.
}

investigating the impact of gender on classification shifting would provide more direct evidence on whether the different behaviors between female and male CEOs in terms of earnings management is because females are more risk-averse, but not necessarily more ethical than male CEOs are. For example, if this study was to find a negative relationship between female CEOs and classification shifting (despite its lower risk), this might demonstrate that female directors are more ethically sensitive than male directors are. On the other hand, if there is a positive relationship, the riskaversion theory might represent the best theory to explain female CEO behavior. Given that both our risk-aversion and ethical theories imply that female CEOs are, on average, less likely to engage in earnings management than male CEOs, including classification shifting, our first hypothesis is set up as follows:

Hypothesis 1 Ceteris paribus, there is a significant negative relationship between female CEOs and the extent of classification shifting.

The extant literature has evaluated the economic consequences of the SOX, which represents one of the most influential reforms of American business practices in a century (Cohen and Zarowin 2010). Apparently, SOX has increased litigation risks and costs because of high possibility of lawsuits that can include a prison term of 25 years and a personal fine of US\$15 million for corporate executives if convicted. However, subsequent to the passage of SOX, prior studies showed that firms tended to switch from the highly risky AEM technique to a less costly method-namely, REM (i.e., Cohen et al. 2008; Cohen and Zarowin 2010; Zang 2012). Therefore, the current study seeks to extend prior accounting studies by investigating whether SOX affects firms' preference towards classification shifting and whether the ethical disposition of female CEOs affects this relationship. Because of the increased cost of AEM (Cohen et al. 2008; Cohen and Zarowin 2010), CEOs might resort to classification shifting, which is a subtle and difficult-to-detect form of earnings management. In that case, we will expect to witness an increase in the use of classification shifting and particularly by highly risk-averse, but not necessarily more ethical than female CEOs (as a less costly earnings management method) post-SOX.

On the other hand, SOX has affected the disclosure requirement of core earnings. Heflin and Hsu (2008) found that SOX has affected core-earnings reporting, and therefore the likelihood of detecting it has become potentially high in post-SOX era. In addition, since external auditors has become more concerned about classification shifting practices (Abernathy et al. 2014), especially in the postSOX era (Chen et al. 2012), female CEOs may not view it as a viable method in the post-SOX era. Abernathy et al.'s 
(2014) findings did not support this proposition; however, they did not differentiate between male and female CEOs. If female CEOs are more ethically sensitive than their male counterparts are, then, we should not expect SOX to affect their attitude towards classification shifting. On the other hand, if female CEOs are more risk-averse than male CEOs are, then, SOX should be expected to affect their behavior towards classification shifting because of the increased disclosure requirement and potential lawsuit filing (Chen et al. 2012). Given these conflicting theoretical arguments, we do not predict a sign for the relationship between female CEOs and classification shifting in the post-SOX era, with our final hypothesis set up as follows:

Hypothesis 2 Ceteris paribus, there is a significant relationship between female CEOs and the extent of classification shifting after the passage of SOX.

\section{Research Method}

\section{Empirical Models}

To investigate whether the gender of CEOs affects the level of classification shifting, which is a more sophisticated, but potentially less litigious form of earnings management (Abernathy et al. 2014), this study focusses on the deliberate misclassification of core expenses, as special items within the income statement (McVay 2006). Consequently, we test the association between unexpected core earnings and special items. We follow McVay (2006) in developing a proxy for normal core earnings being a function of last year's core earnings, current and last years' accruals, asset turnover, and changes in sales, and negative sales. However, since the inclusion of current year's accruals might introduce a mechanical relationship between special items and unexpected core earnings, we follow Fan et al.'s (2010) recommendation and adjust McVay's (2006) model. In particular, we exclude current year's accruals from the McVay (2006) expectation model as follows:

$$
\begin{aligned}
& \mathrm{CE}_{i, t}=\gamma_{0}+\gamma_{1} \mathrm{CE}_{i, t-1}+\gamma_{2} \mathrm{ATO}_{i, t}+\gamma_{3} \mathrm{ACCRUALS}_{i, t-1} \\
& +\gamma_{4} \Delta \text { SALES }_{i, t}+\gamma_{5} \text { NEG_}_{-} \Delta \text { SALES }_{i, t}+u_{i, t} \text {. }
\end{aligned}
$$

The variables in the above equation are measured as follows:

$\mathrm{CE}$
Core earnings/sales. Where core earnings equals (sales - cost of goods sold - selling, general, and adminis-

\begin{tabular}{|c|c|}
\hline ATO & $\begin{array}{l}\text { Asset turnover, defined as sales/ } \\
\text { average net operating assets, where } \\
\text { net operating assets is the differ- } \\
\text { ence between operating assets and } \\
\text { operating liabilities. Operating } \\
\text { assets = total assets - cash and } \\
\text { cash equivalent. Operating liabili- } \\
\text { ties = total assets - total debt - book } \\
\text { value of common equity - preferred } \\
\text { equity - minority interests }\end{array}$ \\
\hline Accruals & $\begin{array}{l}\text { Working capital accruals measured as } \\
\text { (change in total current assets net } \\
\text { of change in cash minus change in } \\
\text { current liabilities net of change in the } \\
\text { current portion of long-term debt)/ } \\
\text { sales }\end{array}$ \\
\hline$\Delta$ Sales & $\begin{array}{l}\text { Change in sales }=\left(\text { sales }_{t}-\text { sales }_{t-1}\right) / \\
\text { sales }_{t-1}\end{array}$ \\
\hline NEG_Sales & $\begin{array}{l}\text { This refers to } \Delta \text { sales if it is negative, } \\
\text { and zero otherwise }\end{array}$ \\
\hline
\end{tabular}
trative expenses)
We estimate Model (1) cross-sectionally by industry and fiscal year in order to obtain variable coefficients that we use to calculate expected core earnings. We then calculate the expected core earnings for each firm by multiplying the coefficients obtained from Model (1) by the actual value of variables in the equation for each firm. We then estimate the following model to investigate whether CEOs' gender affects the level of firms' classification shifting,

$\mathrm{UCE}=\beta_{0}+\beta_{1} \mathrm{SPI}+\beta_{2} \mathrm{FCEO}+\beta_{3} \mathrm{SPI} \times \mathrm{FCEO}+$ Control variables,

where unexpected core earnings (UCE) is the difference between reported core earnings and expected core earnings. Consistent with McVay (2006) and Fan et al. (2010), SPI is special items as a percentage of sales. Special items are multiplied by -1 , when special items are income-decreasing and are set to 0 , when they are income-increasing. FCEO is a dummy variable that is equal to 1 if the CEO is a female and 0 otherwise.

Classification shifting increases both core earnings and special items and, therefore, when firms engage in such practices, $\beta_{1}$ should be positive. ${ }^{10}$ That is, the association between UCE and SPI is the aspect that suggests classification shifting (Zalata and Roberts 2017). In order to

\footnotetext{
$\overline{10}$ Nevertheless, this positive relationship might be due to real improvement in firms' core profitability because of restructuring activities or other real economic events that drive this SPI. Therefore, following McVay (2006), to mitigate this concern, we investigate whether this improved profitability persists into the subsequent year. The reversal of this improvement in profitability will be more consistent with classification shifting. In this case, we should find a negative association between the current year's SPI and the unexpected change in core earnings in the subsequent year. Consistent with classification shifting behavior, our unreported results show a negative relationship between SPI and the unexpected change in firms' core profitability, which supports a classification-shifting behavior.
} 
investigate Hypothesis 1, we therefore include the interactions between SPI and FCEO and expect it to be significant. In addition, the current study controls for firms' characteristics that can affect the level of earnings management.

Zalata and Roberts (2017) suggested that variables that might affect the level of earnings management include firm size (SIZE), leverage (LEV), operating cash flow (OCF), return on assets (ROA), and market-to-book value ratio (MBV). Where SIZE is measured as the natural log of total assets. LEV is measured as ratio of long-term debt to equity. OCF is measured as the cash flows from operations scaled by lagged total assets. ROA is measured as the net income divided by average total assets. MBV is measured as market capitalization scaled by book value of common equity. In addition, Haw et al. (2011) show that the use of a Big4 auditor might affect firms' preference towards classification shifting and therefore, we control for Big4 auditors (AUDIT). AUDIT is an indicator variable set to one if a Big4 auditor audits a firm, and zero otherwise. Additionally, we control for CEO age (CEOAGE).

In order to investigate whether the legal environment affects CEOs' behavior towards classification shifting, we model Eq. 3, and add SOX as a proxy for the change in the legal environment. SOX is an indicator variable that is equal to one if the fiscal year-end is in post-SOX era, and zero otherwise.

The regression model takes the following form:

$$
\begin{aligned}
\mathrm{UCE}= & \beta_{0}+\beta_{1} \mathrm{SPI}+\beta_{2} \mathrm{FCEO}+\beta_{3} \mathrm{SOX}+\beta_{4} \mathrm{SPI} \times \mathrm{FCEO} \\
& +\beta_{5} \mathrm{SPI} \times \mathrm{SOX}+\beta_{6} \mathrm{FCEO} \times \mathrm{SOX}+\beta_{7} \mathrm{SPI} \\
& \times \mathrm{FCEO} \times \mathrm{SOX}+\mathrm{Control} \text { variables }
\end{aligned}
$$

To investigate our hypothesis, we focus on the coefficients of $\beta_{1}, \beta_{4}, \beta_{5}$ and $\beta_{7}$.

\section{Sample Selection and Data Sources}

Financial statement data are obtained for the years 1992 to 2014 from the 2014 Annual Compustat File. ${ }^{11}$ CEO gender and shareholding data are obtained from ExecuComp. Each firm-year observation is required to have sufficient data to calculate variables in Model (1). Since financial firms have a different financial reporting environment, we excluded them from our sample. Similar to prior classification-shifting studies, in order to ensure sufficient data to estimate normal core earnings, we exclude industries with less than eight firmyear observations. After calculating unexpected core earnings, we then merge the financial data with the CEO gender data and we delete observations with missing CEO gender

\footnotetext{
11 Note that 1992 is the earliest year for which the required data is available in the Execucomp database.
}

Table 1 Descriptive statistics

\begin{tabular}{lcllll}
\hline Variables & Mean & Median & $\begin{array}{c}\text { Standard } \\
\text { deviation }\end{array}$ & $25 \%$ & $75 \%$ \\
\hline UCE & 0.03 & 0 & 0.23 & -0.05 & 0.06 \\
SPI & 0.02 & 0 & 0.07 & 0 & 0.02 \\
FCEO & 0.03 & 0 & 0.16 & 0 & 0 \\
SOX & 0.65 & 1 & 0.48 & 0 & 1 \\
SIZE & 7.09 & 6.93 & 1.54 & 5.96 & 8.08 \\
LEV & 0.55 & 0.28 & 1.45 & 0 & 0.69 \\
OCF & 0.12 & 0.11 & 0.1 & 0.06 & 0.17 \\
ROA & 0.04 & 0.05 & 0.11 & 0.01 & 0.1 \\
MBV & 3.13 & 2.27 & 3.59 & 1.42 & 3.71 \\
AUDIT & 0.93 & 1 & 0.25 & 1 & 1 \\
CEOAGE & 53.53 & 55 & 11.91 & 50 & 60 \\
\hline
\end{tabular}

$U C E$ unexpected core earnings, $F C E O$ indicator variable set to one if CEO is female and zero otherwise, SOX indicator variable set to one if firm-year observation is after 2002 and zero otherwise, SIZE the natural $\log$ of total assets, $L E V$ the ratio of long-term debt to total equity, $O C F$ cash flows from operations scaled by lagged total assets, $R O A$ return on assets measured as net income divided by average total assets, $M B V$ market to book value ratio measured as market capitalization divided by book value of common equity, AUDIT indicator variable set to one if a Big4 auditor audits firm, and zero otherwise, CEOAGE CEO age, SPI special items as a percentage of sales (Special items are multiplied by -1 , where special items are income-decreasing, and are set to 0 where special items are incomeincreasing)

and control variables' data. The resulting sample with full data is 21,101 firm-year observations, spanning the period from 1992 to 2014.

\section{Results}

\section{Descriptive Statistics}

Table 1 presents the descriptive statistics of unexpected core earnings (UCE), special items (SPI), female CEOs (FCEO) and other variables used in the analysis. For each variable, we report the mean, the median, standard deviation, and the 25 th and 75 th percentiles. The mean of unexpected core earnings (UCE) as a percentage of sales is 0.03 and the median is 0.00 . The mean of special items as a percentage of sales is 0.02 and the median is equal to 0.00 . Observably, only $3 \%$ of our sample employs women as CEOs. ${ }^{12}$ Table 2 reports the correlation matrix between all variables. It shows a significant positive relationship between SPI and UCE, suggesting that some firms might have misclassified some core expenses as special items. In general, the

\footnotetext{
$\overline{12}$ In particular, in our current sample, a total of 579 firm-year observations have female CEOs, of which 142 belong to the pre-SOX era.
} 
Table 2 Correlation matrix

\begin{tabular}{|c|c|c|c|c|c|c|c|c|c|c|c|}
\hline Variables & UCE & SPI & FCEO & SOX & SIZE & LEV & $\mathrm{OCF}$ & ROA & MBV & AUDIT & CEOAGE \\
\hline UCE & 1 & & & & & & & & & & \\
\hline SPI & $0.13 * * *$ & 1 & & & & & & & & & \\
\hline FCEO & -0.01 & -0.00 & 1 & & & & & & & & \\
\hline SOX & 0.00 & $-0.03 * * *$ & $0.05 * * *$ & 1 & & & & & & & \\
\hline SIZE & $-0.01 *$ & $-0.03 * * *$ & $-0.01 *$ & $0.18 * * *$ & 1 & & & & & & \\
\hline LEV & -0.01 & $0.03 * * *$ & $-0.01 *$ & -0.01 & $0.16^{* * *}$ & 1 & & & & & \\
\hline $\mathrm{OCF}$ & $-0.12 * * *$ & $-0.21 * * *$ & 0.01 & 0.00 & $0.06 * * *$ & $-0.08 * * *$ & 1 & & & & \\
\hline ROA & $-0.15 * * *$ & $-0.58 * * *$ & 0.00 & $0.02 * * *$ & $0.12 * * *$ & $-0.07 * * *$ & $0.64 * * *$ & 1 & & & \\
\hline MBV & $-0.07 * * *$ & $-0.04 * * *$ & -0.00 & $-0.05 * * *$ & 0.01 & $0.43 * * *$ & $0.29 * * *$ & $0.23 * * *$ & 1 & & \\
\hline AUDIT & $-0.02 * *$ & -0.01 & $-0.02 * *$ & $-0.13 * * *$ & $0.24 * * *$ & $0.05 * * *$ & $0.04 * * *$ & $0.05 * * *$ & $0.03 * * *$ & 1 & \\
\hline CEOAGE & -0.01 & $-0.08 * * *$ & $-0.03 * * *$ & $0.11 * * *$ & $0.11 * * *$ & -0.00 & $0.04 * * *$ & $0.10 * * *$ & $-0.03 * * *$ & $-0.02 * * *$ & 1 \\
\hline
\end{tabular}

$U C E$ unexpected core earnings, $F C E O$ indicator variable set to one if CEO is female and zero otherwise, SOX indicator variable set to one if firm-year observation is after 2002 and zero otherwise, SIZE the natural $\log$ of total assets, $L E V$ the ratio of long-term debt to total equity, $O C F$ cash flows from operations scaled by lagged total assets, $R O A$ return on assets measured as net income divided by average total assets, $M B V$ market to book value ratio measured as market capitalization divided by book value of common equity, AUDIT indicator variable set to one if a Big4 auditor audits firm, and zero otherwise, CEOAGE CEO age, SPI special Items as a percentage of sales (Special items are multiplied by - 1, where special items are income-decreasing, and are set to 0 where special items are income-increasing)

*Significance at $0.10, * *$ significance at $0.05, * * *$ significance at 0.01

correlation matrix does not show any potential serious multicollinearity problems.

\section{Multivariate Analyses}

To investigate female CEOs' preference towards classification shifting (Hypothesis 1), we focus on the coefficient of SPI and interaction between SPI and FCEO. The results presented in Table 3 under Model (1) show that the coefficient of SPI is positive and significant at $1 \%$, suggesting that male CEOs might have misclassified some core items as special items within the income statement, and therefore might have inflated their core profitability. The variable of interest, $\mathrm{SPI} \times \mathrm{FCEO}$, is positive, but insignificant, demonstrating that there is no significant difference between male and female CEOs in terms of their preference towards classification shifting as a more sophisticated, but less litigious earnings management method.

Nevertheless, the previous analysis focusses on the whole sample period and ignores the fact that the SOX Act might have affected CEOs' opportunistic behavior. Cohen et al. (2008) showed that the passage of SOX has increased the cost of AEM and, therefore, opportunistic firms might shift to another earnings management method that has a lower detection cost. In these circumstances, classification shifting might represent a viable method. Therefore, we extended the analysis to investigate the impact of SOX on female CEOs' preference towards classification shifting. To investigate this research question, we created an interaction term among SOX, SPI and FCEO. The results of this analysis are reported in Table 3 under Models (2) and (3). In general, our results reported under Model (2) show that while SPI is still positive and significant at $1 \%, \mathrm{SPI} \times \mathrm{SOX}$ is also positive and significant at 5\%, suggesting that increased regulation surrounding financial reporting in the post-SOX era has increased firms' preference towards classification shifting; this may be because of its lower detection cost compared with other earnings management methods. Furthermore, Table 3, under Model (3), reports the results when considering the differences between male and female CEOs in the pre- and post-SOX eras. SPI is still positive and significant at $1 \%$, suggesting that some male CEOs used to employ classification shifting before the SOX. In addition, it shows that SPI $\times$ SOX is positive and significant at $1 \%$, suggesting that male CEOs increased their use of classification shifting, particularly in the post-SOX era. Interestingly, the coefficient on SPI $\times$ FCEO is positive and significant at $5 \%$, suggesting that classification shifting was more prevalent in firms with female CEOs in the pre-SOX period than in firms with their male counterparts.

On the other hand, Table 3 [under Model (3)] shows that the coefficient on the variable of interest, SPI $\times$ FCEO $\times$ SOX, is negative and significant at $1 \%$, demonstrating that classification shifting has become less prominent in firms with female CEOs after the passage of SOX. This suggests that a strong legal environment affects the preference of female CEOs towards classification shifting. That is, female CEOs used to engage in classification shifting before the passage of SOX, after which they have significantly reduced their use of the classification shifting. Again, these results support the proposition that female CEOs are more risk-averse than male 
Table 3 The association between female CEOs and classification shifting (all firms)

\begin{tabular}{|c|c|c|c|c|c|c|}
\hline \multirow[t]{2}{*}{ Variables } & \multicolumn{2}{|l|}{ Model (1) } & \multicolumn{2}{|l|}{ Model (2) } & \multicolumn{2}{|l|}{ Model (3) } \\
\hline & Coefficient & $t$-statistic & Coefficient & $t$-statistic & Coefficient & $t$-statistic \\
\hline SPI & 0.293 & $9.37 * * *$ & 0.220 & $5.12 * * *$ & 0.209 & $4.85 * * *$ \\
\hline FCEO & -0.009 & -0.87 & -0.009 & -0.88 & 0.008 & 0.36 \\
\hline SOX & & & 0.024 & $2.09 * *$ & 0.024 & $2.12 * *$ \\
\hline SPI $\times$ FCEO & 0.030 & 0.19 & 0.010 & 0.06 & 0.749 & $2.41 * *$ \\
\hline $\mathrm{SPI} \times \mathrm{SOX}$ & & & 0.124 & $2.5 * *$ & 0.143 & $2.85 * * *$ \\
\hline $\mathrm{FCEO} \times \mathrm{SOX}$ & & & & & -0.022 & -0.93 \\
\hline $\mathrm{SPI} \times \mathrm{FCEO} \times \mathrm{SOX}$ & & & & & -0.994 & $-2.77 * * *$ \\
\hline SIZE & 0.000 & 0.02 & 0.000 & -0.01 & 0.000 & 0 \\
\hline LEV & 0.001 & 0.4 & 0.000 & 0.32 & 0.000 & 0.34 \\
\hline OCF & -0.114 & $-5.36 * * *$ & -0.115 & $-5.38 * * *$ & -0.114 & $-5.34 * * *$ \\
\hline ROA & -0.132 & $-5.6^{* * *}$ & -0.133 & $-5.64 * * *$ & -0.133 & $-5.66^{* * *}$ \\
\hline MBV & -0.003 & $-5.43 * * *$ & -0.003 & $-5.32 * * *$ & -0.003 & $-5.32 * * *$ \\
\hline AUDIT & -0.008 & -1.17 & -0.008 & -1.14 & -0.008 & -1.15 \\
\hline CEOAGE & 0.000 & 0.76 & 0.000 & 0.7 & 0.000 & 0.69 \\
\hline _CONS & 0.054 & $3.83 * * *$ & 0.054 & $3.81 * * *$ & 0.053 & $3.79 * * *$ \\
\hline YEARS & Included & & Included & & Included & \\
\hline Adj. $R^{2}$ & 0.03 & & 0.03 & & 0.03 & \\
\hline$F$ & 23.97 & & 23.41 & & 22.26 & \\
\hline No. of observations & 21,101 & & 21,101 & & 21,101 & \\
\hline
\end{tabular}

We estimate the parameters using the following model

$\mathrm{UCE}=\beta_{0}+\beta_{1} \mathrm{SPI}+\beta_{2} \mathrm{FCEO}+\beta_{3} \mathrm{SOX}+\beta_{4} \mathrm{SPI} \times \mathrm{FCEO}+\beta_{5} \mathrm{SPI} \times \mathrm{SOX}+\beta_{6} \mathrm{FCEO} \times \mathrm{SOX}+\beta_{7} \mathrm{SPI} \times \mathrm{FCEO}$ $\times \mathrm{SOX}+$ Control variables

Where

FCEO indicator variable set to one if CEO is female and zero otherwise, SOX indicator variable set to one if firm-year observation is after 2002 and zero otherwise, SIZE the natural log of total assets, $L E V$ the ratio of long-term debt to total equity, $O C F$ cash flows from operations scaled by lagged total assets, $R O A$ return on assets measured as net income divided by average total assets, $M B V$ market to book value ratio measured as market capitalization divided by book value of common equity, AUDIT indicator variable set to one if a Big4 auditor audits firm, and zero otherwise, CEOAGE CEO age, SPI special Items as a percentage of sales (Special items are multiplied by -1 , where special items are income-decreasing, and are set to 0 where special items are income-increasing)

*Significance at $0.10, * *$ significance at $0.05, * * *$ significance at 0.01
CEOs, but not necessarily more ethically sensitive than their male counterparts are.

So far, the reported analysis under Table 3 focusses on all firms. However, McVay (2006) and Zalata and Roberts (2017) noted that only some firms are able to deliberately misclassify their core expenses. In particular, they argue that firms with special expenses are more able to engage in classification shifting than other firms are. Hence, compared with the full sample analysis, limiting our analysis to only firms with special expenses (12,169 firm-year observations) might provide more powerful analysis because these firms have greater opportunity to engage in classification shifting; we report the results of this analysis in Table 4. Consistent with our previous analysis, Table 4, under Model (3), still shows that both male and female CEOs used to view classification shifting as a viable earnings management method before the passage of SOX. In particular, it shows that the coefficients on SPI (male CEOs before SOX) and SPI $\times$ FCEO (female CEOs before SOX) are positive and significant at 1 and 5\%, respectively. It seems that male CEOs increased their use of classification shifting in the post-SOX era $(\mathrm{SPI} \times \mathrm{SOX})$, demonstrating that when the cost of AEM becomes high (e.g., because of SOX), male CEOs might seek another earnings management method that has a lower detection cost - such as classification shifting.

Interestingly, our results still suggest that the passage of SOX affected the behavior of female CEOs differently. In particular, it shows that classification shifting has become less prominent in firms with female CEOs in the postSOX era $(\mathrm{SPI} \times \mathrm{FCEO} \times \mathrm{SOX})$ than in the pre-SOX era $(\mathrm{SPI} \times \mathrm{FCEO})$. All these findings suggest that female CEOs are more risk-averse than male CEOs are, and therefore they 
Table 4 The association between female CEOs and classification shifting (firms with income-decreasing SPI)

\begin{tabular}{|c|c|c|c|c|c|c|}
\hline \multirow[t]{2}{*}{ Variables } & \multicolumn{2}{|l|}{ Model (1) } & \multicolumn{2}{|l|}{ Model (2) } & \multicolumn{2}{|l|}{ Model (3) } \\
\hline & Coefficient & $t$-statistic & Coefficient & $t$-statistic & Coefficient & $t$-statistic \\
\hline SPI & 0.324 & $8.55^{* * *}$ & 0.230 & $4.5 * * *$ & 0.218 & $4.24 * * *$ \\
\hline FCEO & 0.004 & 0.3 & 0.004 & 0.32 & -0.007 & -0.19 \\
\hline SOX & & & 0.028 & 1.43 & 0.028 & 1.42 \\
\hline SPI $\times$ FCEO & -0.058 & -0.34 & -0.083 & -0.48 & 0.799 & $2.17 * *$ \\
\hline $\mathrm{SPI} \times \mathrm{SOX}$ & & & 0.155 & $2.73 * * *$ & 0.175 & $3.07 * * *$ \\
\hline $\mathrm{FCEO} \times \mathrm{SOX}$ & & & & & 0.009 & 0.25 \\
\hline $\mathrm{SPI} \times \mathrm{FCEO} \times \mathrm{SOX}$ & & & & & -1.155 & $-2.76^{* * *}$ \\
\hline SIZE & -0.003 & $-1.64 *$ & -0.003 & $-1.68^{*}$ & -0.003 & $-1.68^{*}$ \\
\hline LEV & 0.0003 & 0.2 & 0.0001 & 0.09 & 0.0002 & 0.12 \\
\hline OCF & -0.201 & $-6.4 * * *$ & -0.203 & $-6.46^{* * *}$ & -0.201 & $-6.4 * * *$ \\
\hline ROA & -0.079 & $-2.4 * *$ & -0.080 & $-2.42 * *$ & -0.081 & $-2.45^{* *}$ \\
\hline MBV & -0.003 & $-3.51 * * *$ & -0.003 & $-3.38 * * *$ & -0.003 & $-3.38 * * *$ \\
\hline AUDIT & -0.003 & -0.33 & -0.002 & -0.25 & -0.003 & -0.26 \\
\hline CEOAGE & 0.000 & 0.13 & 0.000 & 0.07 & 0.000 & 0.06 \\
\hline _CONS & 0.061 & $2.63 * * *$ & 0.064 & $2.72 * * *$ & 0.064 & $2.74 * * *$ \\
\hline YEARS & Included & & Included & & Included & \\
\hline Adj. $R^{2}$ & 0.04 & & 0.04 & & 0.04 & \\
\hline$F$ & 17.60 & & 17.28 & & 16.49 & \\
\hline No. of observations & 12,169 & & 12,169 & & 12,169 & \\
\hline
\end{tabular}

We estimate the parameters using the following model

$\mathrm{UCE}=\beta_{0}+\beta_{1} \mathrm{SPI}+\beta_{2} \mathrm{FCEO}+\beta_{3} \mathrm{SOX}+\beta_{4} \mathrm{SPI} \times \mathrm{FCEO}+\beta_{5} \mathrm{SPI} \times \mathrm{SOX}+\beta_{6} \mathrm{FCEO} \times \mathrm{SOX}+\beta_{7} \mathrm{SPI} \times \mathrm{FCEO}$ $\times \mathrm{SOX}+$ Control variables

Where

FCEO indicator variable set to one if CEO is female and zero otherwise, SOX indicator variable set to one if firm-year observation is after 2002 and zero otherwise, SIZE the natural log of total assets, $L E V$ the ratio of long-term debt to total equity, $O C F$ cash flows from operations scaled by lagged total assets, $R O A$ return on assets measured as net income divided by average total assets, $M B V$ market to book value ratio measured as market capitalization divided by book value of common equity, AUDIT indicator variable set to one if a Big4 auditor audits firm, and zero otherwise, CEOAGE CEO age, SPI special items as a percentage of sales (Special items are multiplied by -1 , where special items are income-decreasing, and are set to 0 where special items are income-increasing)

*Significance at $0.10, * *$ significance at $0.05, * * *$ significance at 0.01 reduced their use of classification shifting after the passage of SOX. However, our analysis does not support the proposition that female CEOs are more ethically sensitive than male CEOs; otherwise, they would not have inflated their core earnings using classification shifting before SOX, on average, at a higher level than their male CEOs.

\section{Robustness Analyses}

First, the previous evidence of classification shifting was based on McVay's (2006) expectation model after modifying it following Fan et al. (2010). However, an alternative approach to dealing with the inherent bias associated with McVay's model is to re-estimate unexpected core earnings (UCE) by replacing total accruals with working capital accruals, which do not include depreciation expense and other special-items accruals; this therefore mitigates any bias in McVay's model (Athanasakou et al. 2009; Haw et al. 2011). Therefore, as robustness analysis, UCE is re-estimated by incorporating both current and lag working capital accruals in the expectation model. Using this approach, unreported results support our reported findings under the main analysis.

Second, the extant research shows that some firms have higher incentives to manage earnings than others do and, therefore, in order to increase the power of the results, we repeat our analysis using a sample of firms that have a strong motivation to manage earnings. Prior studies (for example, Baker et al. 2003; Bergstresser and Philippon 2006; Cheng and Warfield 2005; Kuang 2008; McAnally et al. 2008) have showed that CEOs with high stock ownership tend to engage more in earnings management in 
Table 5 The association between female CEOs and classification shifting (firms with high stock ownership firms)

\begin{tabular}{|c|c|c|c|c|c|c|}
\hline \multirow[t]{2}{*}{ Variables } & \multicolumn{2}{|l|}{ Model (1) } & \multicolumn{2}{|l|}{ Model (2) } & \multicolumn{2}{|l|}{ Model (3) } \\
\hline & Coefficient & $t$-statistic & Coefficient & $t$-statistic & Coefficient & $t$-statistic \\
\hline SPI & 0.317 & $7.11 * * *$ & 0.141 & $2.28 * *$ & 0.119 & $1.92 *$ \\
\hline FCEO & -0.027 & $-2.04 * *$ & -0.027 & $-2.05 * *$ & -0.032 & -1.14 \\
\hline SOX & & & 0.014 & 0.93 & 0.014 & 0.92 \\
\hline SPI $\times$ FCEO & -0.283 & -1.42 & -0.342 & $-1.71 *$ & 1.326 & $2.95 * * *$ \\
\hline SPI $\times$ SOX & & & 0.292 & $4.08 * * *$ & 0.334 & $4.61 * * *$ \\
\hline $\mathrm{FCEO} \times \mathrm{SOX}$ & & & & & 0.003 & 0.09 \\
\hline $\mathrm{SPI} \times \mathrm{FCEO} \times \mathrm{SOX}$ & & & & & -2.084 & $-4.15^{* * *}$ \\
\hline SIZE & -0.006 & $-3 * * *$ & -0.006 & $-2.94 * * *$ & -0.006 & $-2.99 * * *$ \\
\hline LEV & 0.001 & 0.32 & 0.0003 & 0.19 & 0.0004 & 0.24 \\
\hline OCF & -0.092 & $-3.3 * * *$ & -0.093 & $-3.37 * * *$ & -0.094 & $-3.39 * * *$ \\
\hline ROA & -0.115 & $-3.72 * * *$ & -0.118 & $-3.79 * * *$ & -0.114 & $-3.69 * * *$ \\
\hline MBV & -0.005 & $-6.18 * * *$ & -0.004 & $-5.98 * * *$ & -0.004 & $-5.97 * * *$ \\
\hline AUDIT & -0.002 & -0.32 & -0.002 & -0.3 & -0.003 & -0.35 \\
\hline CEOAGE & 0.001 & $3.27 * * *$ & 0.001 & $3.22 * * *$ & 0.001 & $3.23 * * *$ \\
\hline _CONS & 0.046 & $2.3^{* *}$ & 0.044 & $2.2 * *$ & 0.045 & $2.25 * *$ \\
\hline YEARS & Included & & Included & & Included & \\
\hline Adj. $R^{2}$ & 0.03 & & 0.03 & & 0.04 & \\
\hline$F$ & 13.11 & & 13.24 & & 12.98 & \\
\hline No. of observations & 10,556 & & 10,556 & & 10,556 & \\
\hline
\end{tabular}

We estimate the parameters using the following model

$\mathrm{UCE}=\beta_{0}+\beta_{1} \mathrm{SPI}+\beta_{2} \mathrm{FCEO}+\beta_{3} \mathrm{SOX}+\beta_{4} \mathrm{SPI} \times \mathrm{FCEO}+\beta_{5} \mathrm{SPI} \times \mathrm{SOX}+\beta_{6} \mathrm{FCEO} \times \mathrm{SOX}+\beta_{7} \mathrm{SPI} \times \mathrm{FCEO}$ $\times \mathrm{SOX}+$ Control variables

Where

$F C E O$ indicator variable set to one if $\mathrm{CEO}$ is female and zero otherwise, SOX indicator variable set to one if firm-year observation is after 2002 and zero otherwise, SIZE the natural log of total assets, $L E V$ the ratio of long-term debt to total equity, $O C F$ cash flows from operations scaled by lagged total assets, $R O A$ return on assets measured as net income divided by average total assets, $M B V$ market to book value ratio measured as market capitalization divided by book value of common equity, AUDIT indicator variable set to one if a Big4 auditor audits firm, and zero otherwise, CEOAGE CEO age, SPI special Items as a percentage of sales (Special items are multiplied by -1 , where special items are income-decreasing, and are set to 0 where special items are income-increasing)

*Significance at $0.10, * *$ significance at $0.05, * * *$ significance at 0.01 order to increase the value of their stocks. ${ }^{13}$ That is, in this sample, female CEOs with high stock ownership might exhibit different behavior towards classification shifting, and therefore we might find no significant differences in

\footnotetext{
13 In addition, prior studies suggest that firms use classification shifting to report earnings growth (or avoid reporting earnings decrease) (see for example, Barua et al. 2010a). Therefore, we repeat our main analysis using a sample of firms that might have met their growth target. In this sample, we may find that female CEOs might have engaged in classification shifting at the same levels as male CEOs did. That is, we start this analysis by determining firms that have met their earnings growth target. Following Barua et al. (2010a), we classify firms as engaging in earnings decreasing avoidance, if they reported increase in their operating earnings per share. Using this sample, our unreported results moderately support our main findings before the introduction of SOX, and significantly support our postSOX findings.
}

female CEOs' preference towards classification shifting, in the pre- and post-SOX periods. In order to test this conjecture, we repeat our analysis using a subsample of firms with high CEO stock ownership. A firm is classified as 'high' stock ownership if its CEO's stock-ownership percentage is more than the sample median. Focussing on these firms, our reported results in Table 5 are qualitatively similar to that reported under the main analysis.

Third, the extant research shows that there are differences between high- and low-debt firms in terms of their preferences towards earnings management (i.e., DeAngelo et al. 1994; Jaggi and Lee 2002; Peltier-Rivest 1999; Saleh and Ahmed 2005). Since highly leveraged firms are scrutinized closely, they have less ability to deceive the market by inflating their reported earnings and, instead, they might engage in downward earnings management. That is, since the focus of our paper is on upward earnings management 
Table 6 The association between female CEOs and classification shifting (lowleverage firms)

\begin{tabular}{|c|c|c|c|c|c|c|}
\hline \multirow[t]{2}{*}{ Variables } & \multicolumn{2}{|l|}{ Model (1) } & \multicolumn{2}{|l|}{ Model (2) } & \multicolumn{2}{|l|}{ Model (3) } \\
\hline & Coefficient & $t$-statistic & Coefficient & $t$-statistic & Coefficient & $t$-statistic \\
\hline SPI & 0.248 & $5.54 * * *$ & 0.050 & 0.86 & 0.027 & 0.46 \\
\hline FCEO & -0.021 & -1.56 & -0.022 & -1.61 & -0.009 & -0.35 \\
\hline SOX & & & 0.009 & 0.52 & 0.010 & 0.55 \\
\hline SPI $\times$ FCEO & 0.127 & 0.66 & 0.057 & 0.3 & 1.225 & $3.39 * * *$ \\
\hline $\mathrm{SPI} \times \mathrm{SOX}$ & & & 0.373 & $5.35^{* * *}$ & 0.415 & $5.88 * * *$ \\
\hline $\mathrm{FCEO} \times \mathrm{SOX}$ & & & & & -0.019 & -0.63 \\
\hline $\mathrm{SPI} \times \mathrm{FCEO} \times \mathrm{SOX}$ & & & & & -1.629 & $-3.82 * * *$ \\
\hline SIZE & -0.001 & -0.55 & -0.001 & -0.46 & -0.001 & -0.43 \\
\hline LEV & 0.006 & $1.82 *$ & 0.007 & $1.99 * *$ & 0.007 & $2.07 * *$ \\
\hline OCF & -0.117 & $-4 * * *$ & -0.119 & $-4.06 * * *$ & -0.116 & $-3.98 * * *$ \\
\hline ROA & -0.176 & $-5.59 * * *$ & -0.176 & $-5.61 * * *$ & -0.178 & $-5.68 * * *$ \\
\hline MBV & -0.006 & $-6.64 * * *$ & -0.006 & $-6.55 * * *$ & -0.006 & $-6.58 * * *$ \\
\hline AUDIT & -0.015 & $-1.78^{*}$ & -0.014 & $-1.73 *$ & -0.015 & $-1.76^{*}$ \\
\hline CEOAGE & 0.000 & 0.29 & 0.000 & 0.15 & 0.000 & 0.14 \\
\hline _CONS & 0.088 & $4.34 * * *$ & 0.086 & $4.25^{* * *}$ & 0.086 & $4.24 * * *$ \\
\hline YEARS & Included & & Included & & Included & \\
\hline Adj. $R^{2}$ & 0.05 & & 0.05 & & 0.05 & \\
\hline$F$ & 18.33 & & 18.71 & & 18.05 & \\
\hline No. of observations & 10,561 & & 10,561 & & 10,561 & \\
\hline
\end{tabular}

We estimate the parameters using the following model

$\mathrm{UCE}=\beta_{0}+\beta_{1} \mathrm{SPI}+\beta_{2} \mathrm{FCEO}+\beta_{3} \mathrm{SOX}+\beta_{4} \mathrm{SPI} \times \mathrm{FCEO}+\beta_{5} \mathrm{SPI} \times \mathrm{SOX}+\beta_{6} \mathrm{FCEO} \times \mathrm{SOX}+\beta_{7} \mathrm{SPI} \times \mathrm{FCEO}$ $\times \mathrm{SOX}+$ Control variables

Where

FCEO indicator variable set to one if CEO is female and zero otherwise, SOX indicator variable set to one if firm-year observation is after 2002 and zero otherwise, SIZE the natural log of total assets, $L E V$ the ratio of long-term debt to total equity, $O C F$ cash flows from operations scaled by lagged total assets, $R O A$ return on assets measured as net income divided by average total assets, $M B V$ market to book value ratio measured as market capitalization divided by book value of common equity, AUDIT indicator variable set to one if a Big4 auditor audits firm, and zero otherwise, CEOAGE CEO age, SPI special items as a percentage of sales (Special items are multiplied by -1 , where special items are income-decreasing, and are set to 0 where special items are income-increasing)

*Significance at $0.10, * *$ significance at $0.05, * * *$ significance at 0.01 using classification shifting, we expect to find our results to be more pronounced in low-leverage firms. In order to test this conjecture, we repeat our analysis using a subsample of low-debt firms. A firm is classified as a low-debt firm if its long-term debt-to-equity ratio is lower than the sample median. We then repeat our analysis for this subsample separately. The results for this analysis are reported in Table 6, and are qualitatively similar to those reported under the main analysis.

Fourth, under the main analysis, we found that female CEOs are less likely to engage in classification shifting in the post-SOX era than in the pre-SOX era. However, these results might be driven by missing variables. In particular, prior research suggests that corporate governance mechanisms, such as institutional shareholders play a key external monitoring role that reduces managers' opportunistic behavior (Bhojraj and Sengupta 2003). Similarly, blockholders have more to lose if their companies have engaged in opportunistic financial reporting decisions, and therefore we expect that the presence of such investors would strengthen a firm's corporate governance structure (Cyert et al. 2002; Shleifer and Vishny 1986). In addition, the length of tenure might affect the ability of a CEO to influence a firm's financial reporting decisions (Ali and Zhang 2015). Finally, the CFO might affect firms' financial reporting decisions as well (Barua et al. 2010b; Jiang et al. 2010) and, therefore, CFO gender might affect classification shifting. That is, as a robustness test, we extend our control variables to include a number of additional corporate governance, $\mathrm{CEO}$ and CFO characteristics, including percentage of institutional ownership (INSTOWN), the presence of blockholders (BLOCK), CEOs' tenure (CEOTEN) and CFO gender (FCFO), where INSTOWN is measured as the number of shares held by institutional shareholders divided by the number of 
Table 7 The association between female CEOs and classification shifting (missing control variables)

\begin{tabular}{|c|c|c|c|c|c|c|}
\hline \multirow[t]{2}{*}{ Variables } & \multicolumn{2}{|l|}{ Model (1) } & \multicolumn{2}{|l|}{ Model (2) } & \multicolumn{2}{|l|}{ Model (3) } \\
\hline & Coefficient & $t$-statistic & Coefficient & $t$-statistic & Coefficient & $t$-statistic \\
\hline SPI & 0.243 & $6.7 * * *$ & 0.205 & $3.92 * * *$ & 0.188 & $3.58 * * *$ \\
\hline FCEO & -0.019 & $-1.74 *$ & -0.019 & $-1.74 *$ & -0.011 & -0.38 \\
\hline SOX & & & 0.016 & 1.13 & 0.016 & 1.13 \\
\hline SPI $\times$ FCEO & 0.108 & 0.67 & 0.097 & 0.6 & 1.291 & $3.33 * * *$ \\
\hline $\mathrm{SPI} \times \mathrm{SOX}$ & & & 0.060 & 1.03 & 0.087 & 1.47 \\
\hline $\mathrm{FCEO} \times \mathrm{SOX}$ & & & & & -0.011 & -0.38 \\
\hline $\mathrm{SPI} \times \mathrm{FCEO} \times \mathrm{SOX}$ & & & & & -1.447 & $-3.4 * * *$ \\
\hline SIZE & 0.005 & $3.4 * * *$ & 0.005 & $3.39 * * *$ & 0.005 & $3.39 * * *$ \\
\hline LEV & 0.000 & 0.06 & 0.000 & 0.02 & 0.000 & 0.03 \\
\hline $\mathrm{OCF}$ & -0.060 & $-2.47 * *$ & -0.061 & $-2.49 * *$ & -0.060 & $-2.45^{* *}$ \\
\hline ROA & -0.143 & $-5.14 * * *$ & -0.143 & $-5.15^{* * *}$ & -0.144 & $-5.17 * * *$ \\
\hline MBV & -0.003 & $-5.47 * * *$ & -0.003 & $-5.43 * * *$ & -0.003 & $-5.43 * * *$ \\
\hline AUDIT & -0.006 & -0.82 & -0.006 & -0.81 & -0.006 & -0.85 \\
\hline CEOAGE & 0.000 & 1.29 & 0.000 & 1.26 & 0.000 & 1.25 \\
\hline CEOTEN & -0.001 & $-3.04 * * *$ & -0.001 & $-3.04 * * *$ & -0.001 & $-3.02 * * *$ \\
\hline INSTOWN & -0.075 & $-6.69 * * *$ & -0.075 & $-6.69 * * *$ & -0.074 & $-6.65 * * *$ \\
\hline BLOCK & 0.007 & $4.96 * * *$ & 0.007 & $4.94 * * *$ & 0.007 & $4.89 * * *$ \\
\hline FCFO & 0.004 & 0.62 & 0.004 & 0.63 & 0.004 & 0.64 \\
\hline _CONS & 0.050 & $2.82 * * *$ & 0.050 & $2.82 * * *$ & 0.050 & $2.83 * * *$ \\
\hline YEARS & Included & & Included & & Included & \\
\hline Adj. $R^{2}$ & 0.03 & & 0.03 & & 0.03 & \\
\hline$F$ & 16.8 & & 16.35 & & 15.79 & \\
\hline No. of observations & 15,976 & & 15,976 & & 15,976 & \\
\hline
\end{tabular}

We estimate the parameters using the following model

$\mathrm{UCE}=\beta_{0}+\beta_{1} \mathrm{SPI}+\beta_{2} \mathrm{FCEO}+\beta_{3} \mathrm{SOX}+\beta_{4} \mathrm{SPI} \times \mathrm{FCEO}+\beta_{5} \mathrm{SPI} \times \mathrm{SOX}+\beta_{6} \mathrm{FCEO} \times \mathrm{SOX}+\beta_{7} \mathrm{SPI} \times \mathrm{FCEO}$ $\times$ SOX + Control variables

Where

$F C E O$ indicator variable set to one if CEO is female and zero otherwise, SOX indicator variable set to one if firm-year observation is after 2002 and zero otherwise, SIZE the natural $\log$ of total assets, $L E V$ the ratio of long-term debt to total equity, $O C F$ cash flows from operations scaled by lagged total assets, $R O A$ return on assets measured as net income divided by average total assets, $M B V$ market to book value ratio measured as market capitalization divided by book value of common equity, AUDIT indicator variable set to one if a Big4 auditor audits firm, and zero otherwise, CEOAGE CEO age, CEOTEN CEO tenure, INSTOWN institutional shareholders measured as the number of shares held by institutional shareholders divided by the number of outstanding shares, $B L O C K$ block holders measured as a dummy variable set to one if the firm has at least one investor holding at least $5 \%$ of firms' outstanding shares and zero otherwise, $F C F O$ female chief financial officer measured as a dummy variable set to one if CFO is a female, and zero otherwise, SPI special items as a percentage of sales (Special items are multiplied by -1 , where special items are income-decreasing, and are set to 0 where special items are income-increasing)

*Significance at $0.10, * *$ significance at $0.05, * * *$ significance at 0.01 outstanding shares. BLOCK is a dummy variable set to one if the firm has at least one investor holding at least $5 \%$ of firms' outstanding shares and zero otherwise. CEOTEN is CEO tenure. FCFO is a dummy variable set to one if $\mathrm{CFO}$ is a female, and zero otherwise. The results of this analysis are reported in Table 7 and they are qualitatively similar to our reported results under the main analysis.

Finally, as a robustness test investigating whether the gender of CEOs affects their preference towards classification shifting, we create a matched sample of firms with male
CEOs to match firms with female CEOs. Arguably, this is a better approach to empirically examine our hypothesis since firms with female CEOs represent only $3 \%$ of our sample. We matched a sample of firms that are similar in terms of all our control variables included in Model (2). In particular, we employ propensity score to match each FCEO firm with a non-FCEO firm using the nearest-neighbor method.

For 579 firms with FCEOs, we find 551 matched samples with male CEOs, and therefore our final sample includes 1102 firm-year observations that we used to re-run Model 
Table 8 The association between female CEOs and classification shifting (matched sample)

\begin{tabular}{|c|c|c|c|c|c|c|}
\hline \multirow[t]{2}{*}{ Variables } & \multicolumn{2}{|l|}{ Model (1) } & \multicolumn{2}{|l|}{ Model (2) } & \multicolumn{2}{|l|}{ Model (3) } \\
\hline & Coefficient & $t$-statistic & Coefficient & $t$-statistic & Coefficient & $t$-statistic \\
\hline SPI & 0.529 & $2.7 * * *$ & 0.722 & $2.64 * * *$ & 0.071 & 0.21 \\
\hline FCEO & -0.019 & -1.37 & -0.019 & -1.36 & 0.045 & 1.5 \\
\hline SOX & & & 0.070 & 1.08 & 0.101 & 1.55 \\
\hline SPI $\times$ FCEO & -0.093 & -0.4 & -0.078 & -0.34 & 1.225 & $2.68 * * *$ \\
\hline $\mathrm{SPI} \times \mathrm{SOX}$ & & & -0.268 & -1.01 & 0.616 & $1.65^{*}$ \\
\hline $\mathrm{FCEO} \times \mathrm{SOX}$ & & & & & -0.082 & $-2.41 * *$ \\
\hline $\mathrm{SPI} \times \mathrm{FCEO} \times \mathrm{SOX}$ & & & & & -1.739 & $-3.31 * * *$ \\
\hline SIZE & 0.000 & 0.01 & 0.000 & 0 & 0.000 & 0.08 \\
\hline LEV & 0.015 & 1.58 & 0.015 & 1.51 & 0.015 & 1.62 \\
\hline OCF & -0.083 & -0.9 & -0.081 & -0.88 & -0.044 & -0.48 \\
\hline ROA & 0.015 & 0.15 & 0.016 & 0.16 & -0.013 & -0.13 \\
\hline MBV & -0.006 & -1.6 & -0.006 & -1.53 & -0.006 & -1.57 \\
\hline AUDIT & -0.002 & -0.09 & -0.004 & -0.15 & -0.001 & -0.05 \\
\hline CEOAGE & 0.000 & 0.44 & 0.000 & 0.42 & 0.000 & 0.34 \\
\hline _CONS & 0.005 & 0.07 & 0.009 & 0.12 & -0.017 & -0.23 \\
\hline YEARS & Included & & Included & & Included & \\
\hline Adj. $R^{2}$ & 0.04 & & 0.04 & & 0.05 & \\
\hline$F$ & 2.37 & & 2.33 & & 2.72 & \\
\hline No. of observations & 1102 & & 1102 & & 1102 & \\
\hline
\end{tabular}

We estimate the parameters using the following model

$\mathrm{UCE}=\beta_{0}+\beta_{1} \mathrm{SPI}+\beta_{2} \mathrm{FCEO}+\beta_{3} \mathrm{SOX}+\beta_{4} \mathrm{SPI} \times \mathrm{FCEO}+\beta_{5} \mathrm{SPI} \times \mathrm{SOX}+\beta_{6} \mathrm{FCEO} \times \mathrm{SOX}+\beta_{7} \mathrm{SPI} \times \mathrm{FCEO}$ $\times$ SOX + Control variables

Where

FCEO indicator variable set to one if CEO is female and zero otherwise, SOX indicator variable set to one if firm-year observation is after 2002 and zero otherwise, SIZE the natural log of total assets, $L E V$ the ratio of long-term debt to total equity, $O C F$ cash flows from operations scaled by lagged total assets, $R O A$ return on assets measured as net income divided by average total assets, $M B V$ market to book value ratio measured as market capitalization divided by book value of common equity, AUDIT indicator variable set to one if a Big4 auditor audits firm, and zero otherwise, CEOAGE CEO age, SPI special items as a percentage of sales (Special items are multiplied by -1 , where special items are income-decreasing, and are set to 0 where special items are income-increasing)

*Significance at $0.10, * *$ significance at $0.05, * * *$ significance at 0.01
(2). The results of this analysis are reported in Table 8 and they still support our main finding that SOX has significantly influenced FCEOs towards classification shifting.

\section{Further Analysis: Other Earnings Management Methods}

Earnings can be managed through financial reporting decisions in a number of ways, including straightforward fraud, AEM, REM and/or classification shifting, but, so far, our analyses have focussed on classification shifting. If the riskaversion theory holds, we expect to see more female CEOs shift from AEM in the post-SOX era. In addition, the extant research (i.e., Cohen and Zarowin 2010; Cohen et al. 2008; Graham et al. 2005; Roychowdhury 2006) suggests that the
post-SOX era is characterized by high REM. That is, one might argue that female CEOs might have adopted alternative earnings management methods-(i.e., REM)—in the post-SOX era. Female CEOs might prefer REM for many reasons, but most importantly, it is not subject to much scrutiny by external auditors and monitors. In addition, real business decisions constitute a significant part of monotonous business decisions, and so it is difficult to distinguish them from normal business decisions (Cohen and Zarowin 2010; Roychowdhury 2006). That is, REM has lesser chance of being detected than either classification shifting or AEM. Consequently, if the risk-aversion theory holds, we might find an increase in REM usage in firms with female CEOs in post-SOX. Therefore, as a further test, we repeat our analysis using alternative measures of managers' opportunistic 
behavior, namely AEM and REM,${ }^{14}$ where AEM is the absolute value of the residual from adjusted Jones (1991) model as follows:

$$
\begin{aligned}
\mathrm{WCA}_{i, t} / \mathrm{AT}_{i, t-1}= & \beta_{0}+\beta_{1} 1 / \mathrm{AT}_{i, t-1}+\beta_{2} \mathrm{Adj}_{-} \mathrm{SALES}_{i, t} / \\
& \mathrm{AT}_{i, t-1}+\beta_{3} \Delta \mathrm{OCF}_{i, t} / \mathrm{AT}_{i, t-1} \\
& +\beta_{4} \mathrm{Neg}_{-} \mathrm{OCF}_{i, t}+\beta_{5} \Delta \mathrm{OCF}_{i, t} / \mathrm{AT}_{i, t-1} \\
& \times \mathrm{Neg}_{-} \mathrm{OCF}_{i, t}+\varepsilon_{i t},
\end{aligned}
$$

where WCA refers to working capital accruals measured as the (change in current assets - change in cash) - (change in current liabilities - change in the current portion of longterm debt). AT refer to total assets. We measure Adj_SALES as the difference between change in sales and changes in accounts receivable. In addition, following Ball and Shivakumar (2006) and Athanasakou et al. (2011), we control for $\triangle \mathrm{OCF}$ and Neg_OCF. $\triangle \mathrm{OCF}$ refers to the changes in operating cash flows $(\triangle \mathrm{OCF})$. Neg_OCF, is a dummy variable set to 1 when $\triangle \mathrm{OCF}$ is less than 0 and 0 otherwise.

Following Cohen and Zarowin (2010) and Cheng et al. (2015), we use two proxies for REM, namely REM1 and REM $2,{ }^{15}$ where REM1 is (UN_DEX + UN_OCF) and REM2 is (UN_DEX + UN_PROD). Following Roychowdhury (2006), UN_DEX, UN_OCF and UN_PROD are the residual from the following three equations run annually for each industry.

$\mathrm{DEX}_{t} / \mathrm{AT}_{t-1}=\beta_{0}+\beta_{1} 1 / \mathrm{AT}_{t-1}+\beta_{2} \mathrm{Sales}_{t} / \mathrm{AT}_{t-1}+e_{i t}$,

$$
\begin{aligned}
\mathrm{OCF}_{t} / \mathrm{AT}_{t-1}= & \beta_{0}+\beta_{1} 1 / \mathrm{AT}_{t-1}+\beta_{2} \text { Sales }_{t} / \mathrm{AT}_{t-1} \\
& +\beta_{3} \Delta \text { Sales }_{t} / \mathrm{AT}_{t-1}+e_{i t}
\end{aligned}
$$

$$
\begin{aligned}
\mathrm{PROD}_{t} / \mathrm{AT}_{t-1}= & \beta_{0}+\beta_{1} 1 / \mathrm{AT}_{t-1}+\beta_{2} \text { Sales }_{t} / \mathrm{AT}_{t-1} \\
& +\beta_{3} \Delta \mathrm{Sales}_{t} / \mathrm{AT}_{t-1}+\beta_{4} \Delta \mathrm{Sales}_{t-1} / \\
& \mathrm{AT}_{t-1}+e_{i t}
\end{aligned}
$$

where DISEX is discretionary expenses measured as the sum of selling, general and administrative, $R \& D$ and advertising expenses. $\Delta$ Sales is the change in sales. PROD is the sum of both change in inventory and cost of goods sold. ${ }^{16}$

\footnotetext{
14 We thank anonymous reviewers for pointing out this issue to us.

15 Roychowdhury (2006), Cohen and Zarowin (2010) and Cheng et al. (2015) noted that some activities might lead to both abnormally high production costs and abnormally low OCF. Therefore, the current study does not combine the three components in order to avoid potential double counting.

${ }^{16}$ For ease of interpretation and following Cohen and Zarowin (2010), we multiply the residuals from Eqs. 5 and 6 by negative one. That is, high UN_DEX and UN_OCF is consistent with high probability that a firm has cut their discretionary expenses or offering more price discount.
}

The results of this analysis are reported in Table 9. For AEM, contrary to our expectation, the sign of FCEO is negative, but insignificant, suggesting that there are no significant differences between female and male CEOs towards AEM in the pre-SOX era. However, the negative sign of FCEO provide a moderate support for the fact that female CEOs are less likely to engage in AEM. Similarly, the coefficient of FCEO $\times$ SOX is negative, but insignificant, demonstrating that the SOX has a moderate impact on female CEOs behavior towards AEM. Interestingly, while our results reported under columns 2 and 3 suggest that female CEOs (FCEO) were less likely to engage in REM (REM1 and REM2) in the pre-SOX era, they are more likely to participate in REM in the post-SOX era; probably because SOX has made it costly to engage in financial reporting decisions-based earnings management. All these suggest that female directors appear to be more risk-averse, but not necessarily more ethical than their male counterparts are.

\section{Conclusion}

Traditionally, the number of women serving in senior corporate executive roles has been low (Carter et al. 2003, 2010). However, concerted national and international governance, regulatory and legal reforms, as well as positive initiatives that have been pursued worldwide over the past three decades have helped in bringing about a steady increase in the number and percentage of women currently occupying such senior corporate executive roles (Adams 2016; Adams and Ferreira 2009; Srinidhi et al. 2011). Much of such positive reform is driven by theoretical and empirical evidence, which suggests that gender-diverse boards not only enhance corporate performance/value by improving independence, monitoring, advisory capacity and resources (Carter et al. 2003, 2010; Gul et al. 2011; Liu et al. 2014; Shrader et al. 1997), but also reduce corporate fraud and wrong-doing through enhancement in risk-aversion and ethical orientation (Ho et al. 2015; Palvia et al. 2015; Peni and Vahamaa 2010; Sun et al. 2017). For example and of close relevance to our current study, the findings of several studies suggest that female directors are associated with: (i) more conservative financial reporting (Ho et al. 2015; Palvia et al. 2015), (ii) higher accounting quality (Barua et al. 2010b), and (iii) lower fraudulent financial reporting (Sun et al. 2017), amongst others.

A major empirical research question that has been investigated less often, however, is whether women executives are more ethical or risk-averse than their male counterparts are. A priori, if women are more risk-averse than ethical, then, we conjecture that with the possibility of facing costly legal action, they are more likely to shift to a more subtle, less risky and difficult-to-detect corporate activity (Abernathy 
Table 9 The association between female CEOs and accruals-based and real earnings management

\begin{tabular}{|c|c|c|c|c|c|c|}
\hline \multirow[t]{2}{*}{ Variables } & \multicolumn{2}{|l|}{ AEM } & \multicolumn{2}{|l|}{ REM1 } & \multicolumn{2}{|l|}{ REM2 } \\
\hline & Coefficient & $t$-statistic & Coefficient & $t$-statistic & Coefficient & $t$-statistic \\
\hline FCEO & -0.006 & -0.81 & -0.064 & $-2.95 * * *$ & -0.115 & $-2.91 * * *$ \\
\hline SOX & 0.027 & $7.09 * * *$ & -0.021 & $-1.76^{*}$ & 0.054 & $2.5 * *$ \\
\hline $\mathrm{FCEO} \times \mathrm{SOX}$ & -0.001 & -0.07 & 0.062 & $2.53 * *$ & 0.084 & $1.87 *$ \\
\hline SIZE & -0.006 & $-15.47 * * *$ & 0.014 & $11.68 * * *$ & 0.035 & $16.21 * * *$ \\
\hline LEV & -0.004 & $-10.25^{* * *}$ & 0.017 & $12.62 * * *$ & 0.034 & $14 * * *$ \\
\hline $\mathrm{OCF}$ & 0.023 & 3.32 & -1.414 & $-64.65^{* * *}$ & -0.687 & $-17.2 * * * 8$ \\
\hline ROA & -0.085 & $-13.47 * * *$ & 0.510 & $25.41 * * *$ & 0.068 & $1.86^{*}$ \\
\hline MBV & 0.003 & $16.44 * * *$ & -0.012 & $-20.62 * * *$ & -0.024 & $-23.4 * * *$ \\
\hline AUDIT & -0.011 & $-4.94 * * *$ & 0.022 & $3.22 * * *$ & 0.057 & $4.51 * * *$ \\
\hline CEOAGE & 0.000 & $-6.72 * * *$ & 0.000 & $2.54 * *$ & 0.001 & $2.84 * * *$ \\
\hline _CONS & 0.109 & $23.26 * * *$ & -0.017 & -1.16 & -0.232 & $-8.62 * * *$ \\
\hline YEARS & Included & & Included & & Included & \\
\hline Adj. $R^{2}$ & 0.08 & & 0.26 & & 0.09 & \\
\hline$F$ & 63.28 & & 235.23 & & 70.99 & \\
\hline No. of observations & 21,034 & & 19,959 & & 19,959 & \\
\hline
\end{tabular}

We estimate the parameters using the following model

$\mathrm{EM}=\beta_{0}+\beta_{1} \mathrm{FCEO}+\beta_{2} \mathrm{SOX}+\beta_{3} \mathrm{FCEO} \times \mathrm{SOX}+$ Control variables

Where

FCEO indicator variable set to one if CEO is female and zero otherwise, SOX indicator variable set to one if firm-year observation is after 2002 and zero otherwise, SIZE the natural $\log$ of total assets, $L E V$ the ratio of long-term debt to total equity, $O C F$ cash flows from operations scaled by lagged total assets, $R O A$ return on assets measured as net income divided by average total assets, $M B V$ market to book value ratio measured as market capitalization divided by book value of common equity, AUDIT indicator variable set to one if a Big4 auditor audits firm, and zero otherwise, CEOAGE CEO age

*Significance at $0.10, * *$ significance at $0.05, * * *$ significance at 0.01 et al. 2014; Alfonso et al. 2015), but one that is nonetheless equally un-ethical (Zalata and Roberts 2016, 2017). The opposite may hold if women are genuinely more ethical than men. The 2002 SOX Act offers a unique empirical setting to test these propositions. This is because since the financial scandals in large companies at the beginning of this century and the passage of the SOX Act, CEOs are more likely to employ sophisticated earnings management methods that are less likely to be detected compared with accruals (Cohen et al. 2008, 2010; McNichols 2000; Stubben 2010; Zang 2012). One of these methods is classification shifting that has been shown to be a viable earnings management method used by firms constrained from using AEM (Zalata and Roberts 2016, 2017). However, we know surprisingly very little about whether CEOs' gender affects their preference when it comes to managing earnings using the classification shifting approach. However, and widely known to be more risk-averse (Croson and Gneezy 2009), female CEOs, arguably, would be equally demotivated to employ both AEM and classification-shifting earnings management approaches if they are both risky and costly to engage in. However, it is not clear how they will behave morally and ethically in dilemma situations, whereby earnings management method, such as classification shifting, that has a lower detection cost is available to be used. This is arguably an important empirical research question given the fact that most firms voluntarily disclose pro-forma earnings and most investors use this information in their investment decisions (Chen et al. 2012).

Consequently and using a sample of US firms over the period from 1992 to 2014, we examine the extent to which the gender of a firm's CEO affects the level of earnings management by classification shifting. Our findings suggest that the pre-SOX period was characterized by high levels of classification shifting in firms with either female CEOs or male CEOs, although our results suggest further that it was more pervasive in firms with female CEOs. By contrast, our results suggest that in the post-SOX era, female CEOs (as more risk-averse executives compared with male CEOs) significantly decreased their usage of classification shifting; therefore, demonstrating that the strong legal environment appears to have affected their behavior towards earnings management. Given this, our evidence appears to support the proposition that differences between female and male CEOs in financial reporting decisions are driven by the fact that female CEOs are more risk-averse than their male rivals, and not necessarily because they are more ethically sensitive. Thus, our findings appear to offer more empirical support for our risk-aversion theory compared with our ethical theory. 
It should be noted, however, that our findings only imply that in dilemmatic situations, female CEOs risk-aversion instincts are more likely to take precedence over their ethical instincts, and thereby making female CEOs to be relatively more risk-averse than ethical. Nevertheless and on comparative basis, female CEOs are, on average, both more ethical and risk-averse compared with their male counterparts.

The findings have implications for auditors, boards of directors, investors, policy-makers and regulatory authorities, who are interested in the quality of reported earnings. For example, our findings have implications for boards of directors in terms of informing their decisions regarding CEOs appointments. Similarly, for auditors, investors and regulators, our findings suggest that they should consider not only the gender of CEOs, but also the legal environment as factors that can influence the propensity for CEOs to manage earnings.

Finally and although our study is robust and important, its limitations need to be explicitly acknowledged. First, it is widely known that the quality of external and internal corporate governance environment can influence the extent to which CEOs are able to manage earnings. Although we have controlled for some governance variables in our current analysis, they are not exhaustive due to data limitations. Future researchers may, therefore, be able to improve upon our findings by including extensive internal (e.g., board structures and gender diversity) and external (e.g., analyst following and media coverage) governance structures. Second, several studies suggest (e.g., Jiang et al. 2010) that the motivations for CFOs to engage in earnings management tend to be different from those of CEOs. Our study, however, focuses on CEOs and although we have tried to control for the gender of CFOs, due to limited data, our test seems to lack full statistical power. Future research, therefore, may seek to replicate our study by focusing mainly on the gender of the CFO, as improved data becomes available. Further and although we have repeated our analysis using alternative earnings management techniques, such as REM approach, future researchers may be able to offer further new insights by conducting a study that compares different techniques, such as fraud, AEM, REM and classification shifting methods concurrently. Finally, while our findings suggest that female CEOs are relatively more risk-averse than ethical, readers should be cautious about this interpretation. In particular and on the other hand, our findings might equally imply that female CEOs did not view classification shifting through the lens of ethical behavior until after the frauds, such as Enron that led to the SOX legislation in the early 2000 s occurred. If women changed their reporting behavior once they started to perceive classification shifting as an ethical behavior, then, differences in ethics between men and women could equally explain our findings. Thus, our findings may be explained by the ethical theory as well. Future research may, therefore, be able to improve upon our analysis through an investigation that focuses on both different risk and ethics-oriented empirical settings by employing all reasonably conceivable earnings management techniques. Such an approach may offer more conclusive explanations to the ethics versus risk-aversion puzzle.

\section{Compliance with Ethical Standards}

Conflict of interest The authors declare that they have no conflict of interest.

Ethical Approval This article does not contain any studies with human participants or animals performed by any of the authors.

Open Access This article is distributed under the terms of the Creative Commons Attribution 4.0 International License (http://creativeco mmons.org/licenses/by/4.0/), which permits unrestricted use, distribution, and reproduction in any medium, provided you give appropriate credit to the original author(s) and the source, provide a link to the Creative Commons license, and indicate if changes were made.

\section{References}

Abbott, L. J., Parker, S., \& Presley, T. J. (2012). Female board presence and the likelihood of financial restatement. Accounting Horizons, 26(4), 607-629.

Abernathy, J. L., Beyer, B., \& Rapley, E. T. (2014). Earnings management constraints and classification shifting. Journal of Business Finance and Accounting, 41(5-6), 600-626.

Adams, R. B. (2016). Women on boards: The superheroes of tomorrow? Leadership Quarterly, 27(3), 371-386.

Adams, R. B., \& Ferreira, D. (2009). Women in the boardroom and their impact on governance and performance. Journal of Financial Economics, 94(2), 291-309.

Alfonso, E., Cheng, C. A., \& Pan, S. (2015). Income classification shifting and mispricing of core earnings. Journal of Accounting, Auditing and Finance. https://doi.org/10.1177/0148558X1557173 8.

Ali, A., \& Zhang, W. (2015). CEO tenure and earnings management. Journal of Accounting and Economics, 59(1), 60-79.

Allee, K. D., Bhattacharya, N., \& Black, E. (2007). Pro forma disclosure and investor sophistication: External validation of experimental evidence using archival data. Accounting, Organizations and Society, 32(3), 201-222.

Arun, T. G., Almahrog, Y. E., \& Aribi, Z. A. (2015). Female directors and earnings management: Evidence from UK companies. International Review of Financial Analysis, 39, 137-146.

Athanasakou, V., Strong, N. C., \& Walker, M. (2011). The market reward for achieving analyst earnings expectations: Does managing expectations or earnings matter? Journal of Business Finance and Accounting, 38(1-2), 58-94.

Athanasakou, V. E., Strong, N. C., \& Walker, M. (2009). Earnings management or forecast guidance to meet analyst expectations? Accounting and Business Research, 39(1), 3-35.

Atkinson, S. M., Baird, S. B., \& Frye, M. B. (2003). Do female mutual fund managers manage differently? Journal of Financial Research, 26(1), 1-18.

Baixauli-Soler, J. S., Lucas-Perez, M. E., Martin-Ugedo, J. F., Minguez-Vera, A., \& Sanchez-Marin, G. (2016). Executive directors' 
compensation and monitoring: The influence of gender diversity on Spanish boards. Journal of Business Economics and Management, 17(6), 1133-1154.

Baker, T., Collins, D., \& Reitenga, A. (2003). Stock-option compensation and earnings management incentives. Journal of Accounting, Auditing and Finance, 18(4), 557-582.

Ball, R., \& Shivakumar, L. (2006). The role of accruals in asymmetrically timely gain and loss recognition. Journal of Accounting Research, 44(2), 207-242.

Barua, A., Davidson, L. F., Rama, D. V., \& Thiruvadi, S. (2010a). CFO gender and accruals quality. Accounting Horizons, 24(1), 25-39.

Barua, A., Lin, S., \& Sbaraglia, A. S. (2010b). Earnings management using discontinued operations. Accounting Review, 85(5), 1485-1509.

Bergstresser, D., \& Philippon, T. (2006). CEO incentives and earnings management. Journal of Financial Economics, 80(3), 511-529.

Bernardi, R. A., \& Arnold, D. F. (1997). An examination of moral development within public accounting by gender, staff level and firm. Contemporary Accounting Research, 14(4), 653-668.

Bhattacharya, N., Black, E. L., Christensen, T. E., \& Mergenthaler, R. (2007). Who trades on pro forma earnings information? Accounting Review, 82, 581-619.

Bhojraj, S., \& Sengupta, P. (2003). Effect of corporate governance on bond ratings and yields: The role of institutional investors and outside directors. The Journal of Business, 76(3), 455-475.

Bradshaw, M., \& Sloan, R. (2002). GAAP versus the street: An empirical assessment of two alternative definitions of earnings. Journal of Accounting Research, 40(1), 42-66.

Bruns, W. J., \& Merchant, K. A. (1990). The dangerous morality of managing earnings. Management Accounting, 72(2), 22-25.

Byrnes, J. P., Miller, D. C., \& Schafer, W. D. (1999). Gender differences in risk taking: A meta-analysis. Psychological Bulletin, 125(3), 367.

Capezio, A., \& Mavisakalyan, A. (2016). Women in the boardroom and fraud: Evidence from Australia. Australian Journal of Management, 41(4), 719-734.

Carter, D. A., D’Souza, F., Simkins, B. J., \& Simpson, W. G. (2010). The gender and ethnic diversity of US boards and board committees and firm financial performance. Corporate Governance: An International Review, 18(5), 396-414.

Carter, D. A., Simkins, B. J., \& Simpson, W. G. (2003). Corporate governance, board diversity, and firm value. Financial Review, 38(1), 33-53.

Chen, L., Krishnan, G., \& Pevzner, M. (2012). Pro forma disclosures, audit fees, and auditor resignations. Journal of Accounting and Public Policy, 31, 237-257.

Cheng, Q., Lee, J., \& Shevlin, T. (2015). Internal governance and real earnings management. The Accounting Review, 91(4), 1051-1085.

Cheng, Q., \& Warfield, T. D. (2005). Equity incentives and earnings management. Accounting Review, 80(2), 441-476.

Cohen, D. A., Dey, A., \& Lys, T. Z. (2008). Real and accrual-based earnings management in the pre- and post-Sarbanes-Oxley periods. Accounting Review, 83(3), 757-787.

Cohen, D. A., \& Zarowin, P. (2010). Accrual-based and real earnings management activities around seasoned equity offerings. Journal of Accounting and Economics, 50(1), 2-19.

Collins, D. (2000). The quest to improve the human condition: The first 1500 articles published in Journal of Business Ethics. Journal of Business Ethics, 26(1), 1-73.

Creswell, J. (2006). How suite it isn't: A dearth of female bosses. New York Times. http://www.nytimes.com/2006/12/17/business/yourm oney $/ 17$ csuite.html?pagewanted $=$ all\&_r=0.

Croson, R., \& Gneezy, U. (2009). Gender differences in preferences. Journal of Economic Literature, 47(2), 448-474.
Cumming, D., Leung, T. Y., \& Rui, O. (2015). Gender diversity and securities fraud. Academy of Management Journal, 58(5), 1572-1593.

Cyert, R. M., Kang, S. H., \& Kumar, P. (2002). Corporate governance, takeovers, and top-management compensation: Theory and evidence. Management Science, 48(4), 453-469.

DeAngelo, H., DeAngelo, L., \& Skinner, D. J. (1994). Accounting choice in troubled companies. Journal of Accounting and Economics, 17(1-2), 113-143.

Dyreng, S., Vashishtha, R., \& Weber, J. (2016). Direct evidence on the informational properties of earnings in loan contracts. SSRN Working Paper.

Elliott, W. B. (2006). Are investors influenced by pro forma emphasis and reconciliations in earnings announcements? Accounting Review, 81(1), 113-133.

Faccio, M., Marchica, M. T., \& Mura, R. (2016). CEO gender, corporate risk-taking, and the efficiency of capital allocation. Journal of Corporate Finance, 39, 193-209.

Fan, Y., Barua, A., Cready, W. M., \& Thomas, W. (2010). Managing earnings using classification shifting: Evidence from quarterly special items. Accounting Review, 85, 1303-1323.

Fine, M. (2009). Women leaders' discursive constructions of leadership. Women's Studies in Communication, 32(2), 180-202.

Francis, B., Hasan, I., Park, J. C., \& Wu, Q. (2015). Gender differences in financial reporting decision making: Evidence from accounting conservatism. Contemporary Accounting Research, 32(3), $1285-1318$.

Francis, B. B., Hasan, I., Wu, Q., \& Yan, M. (2014). Are female CFOs less tax aggressive? Evidence from tax aggressiveness. The Journal of the American Taxation Association, 36(2), 171-202.

Francis, J., Huang, A. H., Rajgopal, S., \& Zang, A. Y. (2008). CEO reputation and earnings quality. Contemporary Accounting Research, 25(1), 109-147.

Francoeur, C., Labelle, R., \& Sinclair-Desgagné, B. (2008). Gender diversity in corporate governance and top management. Journal of Business Ethics, 81(1), 83-95.

Ge, W., Matsumoto, D., \& Zhang, J. L. (2011). Do CFOs have style? An empirical investigation of the effect of individual CFOs on accounting practices. Contemporary Accounting Research, 28(4), 1141-1179.

Graham, J. R., Harvey, C. R., \& Rajgopal, S. (2005). The economics implications of corporate financial reporting. Journal of Accounting and Economics, 40(1/3), 3-73.

Gul, F. A., Srinidhi, B., \& Ng, A. C. (2011). Does board gender diversity improve the informativeness of stock prices? Journal of Accounting and Economics, 51(3), 314-338.

Haw, I. M., Ho, S. S., \& Li, A. Y. (2011). Corporate governance and earnings management by classification shifting. Contemporary Accounting Research, 28(2), 517-553.

Heflin, F., \& Hsu, C. (2008). The impact of the SEC's regulation of non-GAAP disclosures. Journal of Accounting and Economics, 46(2), 349-365.

Ho, S. S., Li, A. Y., Tam, K., \& Zhang, F. (2015). CEO gender, ethical leadership, and accounting conservatism. Journal of Business Ethics, 127(2), 351-370.

Hossain, S., Chapple, L., \& Monroe, G. S. (2016). Does auditor gender affect issuing going-concern decisions for financially distressed clients? Accounting and Finance. https://doi.org/10.1111/ acfi.12242.

Huang, H. W., Rose-Green, E., \& Lee, C. C. (2012). CEO age and financial reporting quality. Accounting Horizons, 26(4), 725-740.

Huang, J., \& Kisgen, D. J. (2013). Gender and corporate finance: Are male executives overconfident relative to female executives. Journal of Financial Economics, 108(2013), 822-839.

Hughey, C. J., \& Sulkowski, A. J. (2012). More disclosure = better CSR reputation? An examination of CSR reputation leaders and 
laggards in the global oil and gas industry. Journal of Academy of Business and Economics, 12(2), 24-34.

Ibrahim, N., \& Angelidis, J. (2009). The relative importance of ethics as a selection criterion for entry-level public accountants: Does gender make a difference? Journal of Business Ethics, 85, 49-58.

Jaggi, B., \& Lee, P. (2002). Earnings management response to debt covenant violations and debt restructuring. Journal of Accounting, Auditing and Finance, 17(4), 295-324.

Jiang, F., Zhu, B., \& Huang, J. (2013). CEO's financial experience and earnings management. Journal of Multinational Financial Management, 23(3), 134-145.

Jiang, J. X., Petroni, K. R., \& Wang, I. Y. (2010). CFOs and CEOs: Who have the most influence on earnings management? Journal of Financial Economics, 96, 513-526.

Jones, J. J. (1991). Earnings management during import relief investigations. Journal of Accounting Research, 29, 193-228.

Khlif, H., \& Achek, I. (2017). Gender in accounting research: A review. Managerial Auditing Journal, 32(6), 627-655.

Kirsch, A. (2017). The gender composition of corporate boards: A review and research agenda. Leadership Quarterly. https://doi. org/10.1016/j.leaqua.2017.06.001.

Krishnan, G. V., \& Parsons, L. M. (2008). Getting to the bottom line: An exploration of gender and earnings quality. Journal of Business Ethics, 78(1-2), 65-76.

Kuang, Y. F. (2008). Performance-vested stock options and earnings management. Journal of Business Finance and Accounting, 35(910), 1049-1078.

Li, N. (2010). Negotiated measurement rules in debt contracts. Journal of Accounting Research, 48(5), 1103-1143.

Liu, Y., Wei, Z., \& Xie, F. (2014). Do women directors improve firm performance in China? Journal of Corporate Finance, 28, $169-184$.

Lo, K. (2008). Earnings management and earnings quality. Journal of Accounting and Economics, 45(2-3), 350-357.

Lund, D. B. (2008). Gender differences in ethics judgment of marketing professionals in the United States. Journal of Business Ethics, 77(4), 501-515.

Martin, A., Nishikawa, T., \& Williams, M. (2009). CEO gender: Effects on valuation and risk. Quarterly Journal of Finance and Accounting, 48(3), 23-40.

McAnally, M. L., Srivastava, A., \& Weaver, C. D. (2008). Executive stock options missed earnings targets and earnings management. Accounting Review, 83(1), 185-216.

Mcguinness, P. B., Vieito, J. P., \& Wang, M. (2017). The role of board gender and foreign ownership in the CSR performance of Chinese listed firms. Journal of Corporate Finance, 42, 75-99.

McNichols, M. F. (2000). Research design issues in earnings management studies. Journal of Accounting and Public Policy, 19(4/5), 313-345.

McVay, S. (2006). Earnings management using classification shifting: An examination of core earnings and special items. Accounting Review, 81, 501-531.

Merchant, K. A., \& Rockness, J. (1994). The ethics of managing earnings: An empirical investigation. Journal of Accounting and Public Policy, 13(1), 79-94.

Ntim, C. G. (2015). Board diversity and organizational valuation: Unravelling the effects of ethnicity and gender. Journal of Management and Governance, 19(1), 167-195.

Owhoso, V. (2002). Mitigating gender-specific superior ethical sensitivity when assessing likelihood of fraud risk. Journal of Managerial Issues, 14(3), 360-374.

Palvia, A., Vähämaa, E., \& Vähämaa, S. (2015). Are female CEOs and chairwomen more conservative and risk averse? Evidence from the banking industry during the financial crisis. Journal of Business Ethics, 131(3), 577-594.

Peltier-Rivest, D. (1999). The determinants of accounting choices in troubled companies. Quarterly Journal of Business and Economics, 38, 28-44.

Peni, E., \& Vahamaa, S. (2010). Female executives and earnings management. Managerial Finance, 36(7), 629-645.

Powell, M., \& Ansic, D. (1997). Gender differences in risk behaviour in financial decision-making: An experimental analysis. Journal of Economic Psychology, 18(6), 605-628.

Roychowdhury, S. (2006). Earnings management through real activities manipulation. Journal of Accounting and Economics, 42(3), 335-370.

Saleh, N. M., \& Ahmed, K. (2005). Earnings management of distressed firms during debt renegotiation. Accounting and Business Research, 35(1), 69-86.

Shleifer, A., \& Vishny, R. W. (1986). Large shareholders and corporate control. Journal of Political Economy, 94(3, Part 1), 461-488.

Shrader, C. B., Blackburn, V. B., \& Iles, P. (1997). Women in management and firm financial performance: An exploratory study. Journal of Managerial Issues, 9(3), 355-372.

Simga-Mugan, C., Daly, B. A., Onkal, D., \& Kavut, L. (2005). The influence of nationality and gender on ethical sensitivity: An application of the issue-contingent model. Journal of Business Ethics, 57(2), 139-159.

Srinidhi, B., Gul, F. A., \& Tsui, J. (2011). Female directors and earnings quality. Contemporary Accounting Research, 28(5), $1610-1644$.

Stubben, S. R. (2010). Discretionary revenues as a measure of earnings management. Accounting Review, 85(2), 695-717.

Sun, J., Kent, P., Qi, B., \& Wang, J. (2017). Chief financial officer demographic characteristics and fraudulent financial reporting in China. Accounting and Finance. https://doi.org/10.1111/ acfi. 12286.

Sun, J., Liu, G., \& Lan, G. (2011). Does female directorship on independent audit committees constrain earnings management? Journal of Business Ethics, 99(3), 369-382.

Terjesen, S., Sealy, R., \& Singh, V. (2009). Women directors on corporate boards: A review and research agenda. Corporate Governance: An International Review, 17(3), 320-337.

Welbourne, T. M., Cycyota, C. S., \& Ferrante, C. J. (2007). Wall Street reaction to women in IPOs: An examination of gender diversity in top management teams. Group and Organization Management, 32(5), 524-547.

Ye, K., Zhang, R., \& Rezaee, Z. (2010). Does top executive gender diversity affect earnings quality? A large sample analysis of Chinese listed firms. Advances in Accounting, 26(1), 47-54.

Zalata, A., \& Roberts, C. (2016). Internal corporate governance and classification shifting practices: An analysis of UK corporate behavior. Journal of Accounting, Auditing and Finance, 31(1), 51-78.

Zalata, A. M., \& Roberts, C. (2017). Managing earnings using classification shifting: UK evidence. Journal of International Accounting, Auditing and Taxation, 29, 52-65.

Zalata, A. M., Tauringana, V., \& Tingbani, I. (2018). Audit committee financial expertise, gender, and earnings management: Does gender of the financial expert matter? International Review of Financial Analysis, 55, 170-183.

Zang, A. Y. (2012). Evidence on the trade-off between real activities manipulation and accrual-based earnings management. Accounting Review, 87(2), 675-703. 